\title{
Politeness and Impoliteness
}

\author{
Jonathan Culpeper (Lancaster University)
}

\section{Introduction}

Thirty or so years ago politeness was a specialist, even somewhat esoteric topic, primarily located in pragmatics. Indeed, Penelope Brown and Stephen Levinson's 1978 book - the book that was to become so central to the area - was in fact bundled with another piece on questions and published as part of a collection edited by Esther Goody. Today, seven of the most cited articles published by the Journal of Pragmatics involve politeness or impoliteness, according to the publisher's website. Furthermore, the field now has its own dedicated journal: the Journal of Politeness Research. The surge in politeness studies has had profound effects on the study of pragmatics. As O'Driscoll (2007: 465) points out, Brown and Levinson's "great achievement has been to put socio-pragmatic concerns at the forefront of pragmatic research and the affective aspects of communication firmly on the pragmatics map". Moreover, the multidisciplinary nature of politeness studies, something which undoubtedly has contributed to its popularity, has been strengthened. Although the conceptual heart of the field is still located in pragmatics, models of politeness have been applied and sometimes refined in diverse disciplines, including psychology (especially social psychology), anthropology, sociology, cultural studies, literary studies and behavioural organisation.

Section 2 immediately following is devoted to politeness and is the largest section in this chapter. After some consideration of definitions of politeness in section 2.1, the discussion is structured according to two waves in the politeness literature. The first, in section 2.2, involves the pioneers who created the "classic" models of politeness in the 1970s and 1980s, and also the scholars who applied their model and offered specific criticisms of it mostly in the 1980s and 1990s. What is articulated here is generally a more pragmatic view of politeness. The second, in section 2.3, involves the scholars who in the 1990s and 2000s argued for the rejection (or at least radical revision) of the classic models, some of whom also proposed alternative models. What is articulated here is generally a more socio-cultural view of politeness (a few alternative models also attend to core aspects of pragmatic theory in their proposals). Section 3 of this chapter focuses more closely on the new burgeoning subfield of impoliteness. And finally, the concluding section of this chapter returns to the definition of politeness and suggests what might be referred to as the attitudinal view of politeness.

\section{Politeness}

\subsection{Definitions of politeness}

What might politeness encompass? For somebody who has been invited to dinner in England, politeness might include remembering to use please when you want something passed, complimenting the cook on the food and definitely not burping. Each of these three things involves complexities that work on politeness attempts to account for. The word please is the 'magic word' that British parents impress upon their children to use with all requests, and it looms large in the British psyche. But how is it actually used by adults? Aijmer (1996: 166-8) provides some evidence. It matters how the rest of the request is worded: please is most likely to 
A final draft of: Culpeper, Jonathan (2011) Politeness and impoliteness. In: Karin Aijmer and Gisle Andersen (eds.) Sociopragmatics, Volume 5 of Handbooks of Pragmatics edited by Wolfram Bublitz, Andreas H. Jucker and Klaus P. Schneider. Berlin: Mouton de Gruyter, 391-436. This is the final draft submitted, but it may have very minor errors and infelicities.

be used in conjunction with an imperative (e.g. 'please make me a cup of tea') or with could you (e.g. 'could you please make me a cup of tea'), but much less likely to be used with can you or will you. Differences in situation would influence whether you use the word please. Please tends to be used in relatively formal situations, and in business letters and written notices. It is particularly frequent in service encounters, notably telephone service encounters. So, if the dinner were a formal invitation, please would more likely be used. Complimenting the cook on the food may seem a straightforwardly nice thing to do, but it is not: you place the recipient of the compliment in a rather tricky position. If they simply accept the compliment, they may sound rather immodest, but if they simply reject it, they may offend the person who made it. Consequently, responses to compliments tend to weave a path between these two positions. A response such as 'it's kind of you to say that' suggests that the compliment is (at least in part) a product of the complimenter's kindness and not necessarily a true reflection of the value of the food. Finally, even burping cannot always with certainty be seen as the antithesis of politeness. Cultural considerations clearly come into play here. In some cultures (e.g. on the Indian subcontinent), burping may be acceptable, or even a sign of appreciation of the food - a compliment. Culture also keenly influences all aspects of politeness. The use of the word please is more typical of British culture than North American, being used about twice as frequently (Biber et al. 1999: 1098). This is not to say that American culture is less polite. There are other ways of doing politeness, and those other ways might be evaluated as polite by North Americans, just as using please in certain contexts might be evaluated as polite by British English people. (Im)politeness is in the eyes and ears of the beholder.

Politeness, then, involves 'polite' behaviours. What those behaviours, linguistic and nonlinguistic, consist of, how they vary in context, and why they are considered 'polite' are some of the key areas of politeness study. What exactly is politeness? This is one of the most intractable questions in the field, to which a multitude of answers have been proposed. Bargiela-Chiappini (2003: 1464) comments: 'Despite the variety of studies which focus on linguistic politeness [...] the field still lacks an agreed definition of what 'politeness' is.' Although this state of affairs is not conducive to the development of certain aspects of the field, work undertaken to develop definitions and approaches to politeness can at least help deepen one's appreciation of the issues. Let us survey some of those definitions and approaches.

The classic, and most frequently cited, politeness studies lean heavily towards a pragmatic view of politeness. Specifically, these studies have concentrated on how we employ communicative strategies to maintain or promote social harmony:

[The role of the Politeness Principle is] to maintain the social equilibrium and the friendly relations which enable us to assume that our interlocutors are being cooperative in the first place. (Leech 1983a: 82)

... politeness, like formal diplomatic protocol (for which it must surely be the model), presupposes that potential for aggression as it seeks to disarm it, and makes possible communication between potentially aggressive parties. (Brown and Levinson 1987: 1)

Politeness can be defined as a means of minimizing confrontation in discourse - both the possibility of confrontation occurring at all, and the possibility that a confrontation will be perceived as threatening. (R. Lakoff 1989: 102) 
A final draft of: Culpeper, Jonathan (2011) Politeness and impoliteness. In: Karin Aijmer and Gisle Andersen (eds.)

Sociopragmatics, Volume 5 of Handbooks of Pragmatics edited by Wolfram Bublitz, Andreas H. Jucker and Klaus P. Schneider.

Berlin: Mouton de Gruyter, 391-436. This is the final draft submitted, but it may have very minor errors and infelicities.

Thomas summarises the research agenda of scholars like the above engaged in the study of pragmatic politeness:

All that is really being claimed is that people employ certain strategies (including the 50+ strategies described by Leech, Brown and Levinson, and others) for reasons of expediency - experience has taught us that particular strategies are likely to succeed in given circumstances, so we use them. (Thomas 1995: 179)

In the dinner table scenario, an example would be the choice of linguistic strategy in order to achieve the goals of both being passed something and maintaining harmonious social relations, despite inconveniencing the target of our request. For example, one's experience may lead one to decide that 'could you pass the salt please' is more expedient at a formal dinner event than 'pass the salt'.

The socio-cultural view of politeness emphasises the social context. More specifically, the emphasis is on either (or more often both) social norms or the constructions of participants (i.e. the notions which participants use to understand each other rather than which researchers use to understand participants). Regarding social norms, this view of politeness is neatly summed up by Fraser (1990: 220):

Briefly stated, [the socio-cultural view] assumes that each society has a particular set of social norms consisting of more or less explicit rules that prescribe a certain behavior, a state of affairs, or a way of thinking in context. A positive evaluation (politeness) arises when an action is in congruence with the norm, a negative evaluation (impoliteness = rudeness) when action is to the contrary. (Fraser 1990: 220)

Politeness, in this sense, subsumes notions such as 'good manners', 'social etiquette', 'social graces' and 'minding your ps and qs'. For example, parents teaching their children to say please typically proscribe requests that are not accompanied by that word. Note that social norms are sensitive to context: the social politeness norms that pertain to a family dinner are rather different from those pertaining to an invited formal dinner occasion. In fact, there are some situations where communicative behaviours are not subject to politeness prescriptions; in other words, situations in which behaviours which might be viewed as 'impolite' are unrestricted and licensed. Often, such situations are characterised by a huge power imbalance, as might be the case in army recruit training. But not necessarily so: Harris (2001), for example, describes the sanctioned impoliteness that takes place in the UK's House of Commons, giving Opposition MPs opportunities to attack the Government that they might not have had in other contexts.

Regarding the constructions of participants, let us turn to Richard Watts, whose work on politeness, spanning more than two decades, culminated in his 2003 book, the most important work on politeness in recent years. He writes:

We take first-order politeness to correspond to the various ways in which polite behaviour is perceived and talked about by members of socio-cultural groups. It encompasses, in other words, commonsense notions of politeness. Second-order politeness, on the other hand, is a theoretical construct, a term within a theory of social behaviour and language usage. (Watts et al. 2005a [1992]: 3; see also Watts 2003, Eelen 2001; my emphasis) 
A theory of politeness 2 should concern itself with the discursive struggle over politeness, i.e. over the ways in which (im)polite behaviour is evaluated and commented on by lay members and not with ways in which social scientists lift the term '(im)politeness' out of the realm of everyday discourse and evaluate it to the status of a theoretical concept in what is frequently called Politeness Theory (Watts 2003: 9).

What Watts refers to as second-order politeness (or politeness $)_{2}$ ) is the stuff of the pragmatic view previously mentioned, or what in this chapter constitutes the first wave of politeness research. What he refers to as first-order politeness (or politeness ${ }_{1}$ ), which constitutes the second wave, is like the social norm view of politeness in that it connects with "commonsense notions of politeness", but it is more specific in that it argues that politeness exists in the articulations of lay members and not researchers. One problem with approaching politeness in this way is that researchers are reticent to define politeness precisely, because we are to be guided by the definitions of participants. But one may wonder how we are to recognise a participant's definition of politeness as such, if we have nothing to guide us. In fact, Watts (2003:14) does identify one "fundamental aspect of what is understood as 'polite' behaviour in all [...] cultures" and that is displaying "consideration" for others, something which is also partly reflected in the pragmatic view of politeness (Goffman 1967: 11 also notes the importance of "considerateness").

These different definitions of politeness have largely evolved as a consequence of different agendas. Watts is concerned with 'developing a theory of social politeness' (2003: 9, et passim); the pragmatic approach has a different agenda:

The starting point of pragmatics is primarily in language: explaining communicative behaviour. By studying this we keep our feet firmly on the ground, and avoid getting lost too easily in abstractions such as 'face' or 'culture'. The basic question is: What did s mean [to convey] by saying X?. It is useful to postulate the Politeness Principle (PP), I claim, not because it explains what we mean by the word 'politeness' (an English word which in any case doesn't quite match similar words in other languages), but because it explains certain pragmatic phenomena [...] (Leech 2003: 104-5)

However, whilst there are important differences, not least of all ontological, there is common ground between these two views, and perhaps more than the quotation from Leech above in particular seems to acknowledge. Pragmatic choices are not made in a vacuum but in the light of repeated experience of social situations (and their associated norms) which may lead one to expect certain kinds of interaction to happen, to be able to hypothesise what others' expectations are and to know how to meet them. And once interaction has started we monitor how participants are constructing and orienting to politeness and adjust our pragmatic choices accordingly. Meanings, including understandings of politeness, thus emerge in the flux of social interaction. I will return to these definitional issues in the final section of this chapter, but first let us survey the various approaches to politeness in more detail.

\subsection{First-wave approaches to politeness}

\subsubsection{The classic models}


A final draft of: Culpeper, Jonathan (2011) Politeness and impoliteness. In: Karin Aijmer and Gisle Andersen (eds.)

Sociopragmatics, Volume 5 of Handbooks of Pragmatics edited by Wolfram Bublitz, Andreas H. Jucker and Klaus P. Schneider. Berlin: Mouton de Gruyter, 391-436. This is the final draft submitted, but it may have very minor errors and infelicities.

The classic theories of politeness draw, as one might guess, on the classic pragmatic theories, notably, Conversational Implicature (e.g. Grice 1975) and Speech Act Theory (e.g. Austin 1962; Searle 1969). The bulk of the work in politeness studies has been based on or related to Brown and Levinson (1987). Before attending to that, I will outline an alternative theory.

\section{Maxim-based politeness}

Robin Lakoff (1973) was the first to posit a maxim-based view of politeness. In brief, she proposes that there are two rules of pragmatic competence, one being 'be clear', which is formalised in terms of Grice's (1975) Cooperative Principle, and the other being 'be polite', which is formalised in terms of a Politeness Principle. The latter Politeness Principle consists of the following maxims: (1) Don't Impose, (2) Give Options, and (3) Make your receiver feel good. Lakoff notes that sometimes the need for clarity would clash with the need for politeness, as later would also Leech (e.g. 1983a). But unlike Leech (e.g. 1983a), she goes further and argues that 'it is more important in a conversation to avoid offense than achieve clarity' (1973: 297). There are indeed many occasions in which conveying a potentially offensive message implicitly is a means of upholding politeness. However, we must be careful not to assume that implicitness or indirectness always conveys politeness. For example, the utterance 'you must have shit for brains' is more likely an implicit way of conveying impoliteness.

Leech (1983a) is a much more developed maxim-based approach to politeness. Leech (1983a; see also 1977) posits the Politeness Principle, which is involved in 'trade-offs' with the Cooperative Principle (Grice 1975). In fact, it lends the Cooperative Principle much explanatory power: the Cooperative Principle accounts for how people convey indirect meanings, the Politeness Principle accounts for why people convey indirect meanings. Let us illustrate how this might work with an example from a play (this is analysed in Leech 1992):

[Context: The waiter, as the most tactful communicator, has been chosen to convey some bad news to Crampton, namely, that he is Philips' father.]

Waiter: [smoothly melodious] Yes, sir. Great flow of spirits, sir. A vein of pleasantry, as you might say sir... The young gentleman's latest is that you're his father.

Crampton: What!

Waiter: $\quad$ Only his joke, sir, his favourite joke. Yesterday I was to be his father ... (G.B. Shaw's You Never Can Tell, II, 248)

The waiter does manage to express the information about Crampton's parentage. However, in order to avoid upset (i.e. to maintain politeness), he sacrifices the Maxim of Quality in pretending that this information is untrue, merely a joke.

Leech (1983a:81) defines the Politeness Principle as follows: "'Minimize (other things being equal) the expression of impolite beliefs [...] (Maximize (other things being equal) the expression of polite beliefs")' [there is a corresponding, but less important, positive version]. Note that the Politeness Principle is not confined to dealing with impolite beliefs. Leech's Maxims allow for the minimisation of impolite beliefs and the maximisation of polite beliefs. For example, the direct command 'Have a drink' would appear to be impolite in restricting the hearer's freedom of action, but in fact it maximises the politeness of the belief that the target would wish to have a drink. The Politeness Principle consists of the following maxims: 
1) TACT MAXIM (in impositives and commissives)

(a) Minimize cost to other [(b) Maximize benefit to other]

2) GENEROSITY MAXIM (in impositives and commissives)

(a) Minimize benefit to self [(b) Maximize cost to self]

3) APPROBATION MAXIM (in expressives and assertives)

(a) Minimize dispraise of other [(b) Maximize praise of other]

4) MODESTY MAXIM (in expressives and assertives)

(a) Minimize praise of self [(b) Maximize dispraise of self]

5) AGREEMENT MAXIM (in assertives)

(a) Minimize disagreement between self and other

[(b) Maximize agreement between self and other]

6) SYMPATHY MAXIM (in assertives)

(a) Minimize antipathy between self and other

[(b) Maximize sympathy between self and other] (Leech 1983a: 132)

The Tact maxim is discussed at some length (1983a: chapter 5). Leech states that tact will be influenced by the following social parameters

(i) the greater the cost $\mathrm{A}$ to $\mathrm{h}$,

(ii) the greater the horizontal social distance of $\mathrm{h}$ from $\mathrm{s}$,

(iii) the greater the authoritative status of $\mathrm{h}$ with respect to $\mathrm{s}$,

(iv) the greater will be the need for optionality, and correspondingly for indirectness, in the expression of an impositive, if $s$ is to observe the Tact Maxim.

The first three parameters are also key to Brown and Levinson's (1987) model, so I will not elaborate on them here. Leech is careful not to claim that these maxims apply universally to all cultures, but instead suggests that the Politeness Principle maxims may be weighted differently in different cultures (1983a:150). For example, the Tact Maxim might be a strong feature of some British cultures, Modesty of some Japanese cultures and Generosity of some Mediterranean cultures.

\section{Face-based politeness}

In the field of politeness, Brown and Levinson's work (1987) is the best known and the most researched. In their work they attempt to relate the following aspects: face, facework and acts that threaten face, sociological variables influencing face threat, and five general ways (or 'superstrategies') of counterbalancing face threat with (at least some) specific linguistic strategies. I shall cover these aspects in the following paragraphs.

What is face? Notions such as reputation, prestige, and self-esteem, all involve an element of face. The term is perhaps most commonly used in English in the idiom "losing face", meaning that one's public image suffers some damage, often resulting in humiliation or embarrassment. Such reactions are suggestive of the emotional investment in face. Although the concept of face 
A final draft of: Culpeper, Jonathan (2011) Politeness and impoliteness. In: Karin Aijmer and Gisle Andersen (eds.)

Sociopragmatics, Volume 5 of Handbooks of Pragmatics edited by Wolfram Bublitz, Andreas H. Jucker and Klaus P. Schneider.

Berlin: Mouton de Gruyter, 391-436. This is the final draft submitted, but it may have very minor errors and infelicities.

seems to hail from China (cf. Hu 1944; Ho 1976), much modern writing on face draws upon the work of Goffman (e.g. 1967). Goffman defines it thus:

the positive social value a person effectively claims for himself by the line others assume he has taken during a particular contact. Face is an image of self delineated in terms of approved social attributes. (1967: 5)

This is echoed in Brown and Levinson's scheme, but there are important differences. One such difference is that they posit two related components of face. "Positive face" is defined (clearly echoing Goffman) thus: "the want of every member that his wants be desirable to at least some others ... in particular, it includes the desire to be ratified, understood, approved of, liked or admired" (1987: 62). "Negative face" is defined as "the want of every competent adult member that his actions be unimpeded by others" (1987: 62). Note that face is couched in terms of psychological "wants", and also that they assume these to be universal ("every member wants to claim for himself" (1987: 61)).

Facework, according to Goffman, is made up of "the actions taken by a person to make whatever he [sic] is doing consistent with face" (1967: 12). Any action that impinges to some degree upon a person's face (typically, orders, insults, criticisms) is a face threatening act (hereafter, FTA). People are generally motivated to avoid FTAs, and are willing to incur costs in order to save face (Brown 1970). Facework can be designed to maintain or support face by counteracting threats, or potential threats, to face. This kind of facework is often referred to as redressive facework, since it involves the redress of a FTA. Brown and Levinson's discussion of politeness is confined to this kind of redressive facework. Brown and Levinson (e.g. 1987: 70) claim that politeness can be distinguished according to the type of face addressed, positive or negative. Thus, requests are typically oriented to negative face (they typically impose on one's freedom of action) and criticisms to positive (they typically detract from the positive values one lays claim to). This distinction has been retained or stated as necessary by many other researchers (e.g. Baxter 1984; Craig et al. 1986; Penman 1990; Tracy 1990). Brown and Levinson also make a distinction - although not one that they elaborate on - between FTAs that primarily threaten the hearer's face and those that primarily threaten the speaker's face (1987: 658). Among the former they include orders, requests, threats, criticism, contradictions, and the mention of taboo topics; among the latter, expressing thanks, unwilling promises and offers, apologies, the breakdown of physical control over one's body, and confessions. The selection of politeness is dependent in part on who has their face threatened, self and/or other, though, as Brown and Levinson (1987: 286) hint, it is not always the case that facework is targeted at the recipient of the apparent greatest face threat. Brown and Levinson make the assumption that it is of 'mutual interest' (1987: 60) for interactants to cooperate by supporting each other's face: 'In general, people cooperate (and assume each other's cooperation) in maintaining face, such cooperation being based on the mutual vulnerability of face' (1987: 61). A threat would lead to a counter-threat. Thus, the speaker has a vested interest in maintaining the hearer's face, since this will enhance the probability of reciprocal facework.

Brown and Levinson (1987) argue that an assessment of the amount of face threat of a particular act involves three sociological variables defined thus (summarised from 1987: 74-8): 
A final draft of: Culpeper, Jonathan (2011) Politeness and impoliteness. In: Karin Aijmer and Gisle Andersen (eds.)

Sociopragmatics, Volume 5 of Handbooks of Pragmatics edited by Wolfram Bublitz, Andreas H. Jucker and Klaus P. Schneider.

Berlin: Mouton de Gruyter, 391-436. This is the final draft submitted, but it may have very minor errors and infelicities.

1) Distance (D) is a symmetric social dimension of similarity/difference between the speaker and the hearer. It is often based on the frequency of interaction. The reciprocal giving and receiving of positive face is symptomatic of social closeness.

2) Relative Power $(\mathrm{P})$ of the hearer over the speaker is an asymmetric social dimension. It is the degree to which a participant can impose his/her own plans and self-evaluation.

Deference is symptomatic of a great power differential.

3) Absolute Ranking (R) refers to the ordering of impositions according to the degree to which they impinge upon an interactant's face wants in a particular culture and situation. Negative face impositions can be ranked according to the expenditure (a) of services (including the provision of time) and (b) of goods (including non-material goods like information, as well as the expression of regard and other face payments). Positive face impositions can be ranked according to the amount of "pain" suffered by the other, based on the discrepancy between the other's self-image and that presented in the FTA.

For example, asking a new colleague for a cup of tea is more face threatening than asking a long standing colleague (the distance variable); asking one's employer for a cup of tea is more face threatening than asking a colleague (the power variable); and asking for a glass of vintage port is more face threatening than asking for a glass of water (the ranking variable). Brown and Levinson argue that these three variables subsume all other factors that can influence an assessment of face threat. They suggest that numerical values could be attached to each variable, and that the variables can be summed up to provide an act's weightiness (W) or expected amount of face threat according to the following formula: $\mathrm{W}_{x}=\mathrm{D}(\mathrm{S}, \mathrm{H})+\mathrm{P}(\mathrm{H}, \mathrm{S})+\mathrm{R}_{x}$ (Brown and Levinson 1987: 76). The point of calculating face threat, according to Brown and Levinson, is that it will lead to 'a determination of the level of politeness with which, other things being equal, an FTA will be communicated' (1987: 76). They do not, however, attempt to apply this formula in a quantitative analysis of face threat (see section 2.2.2, for studies by other scholars that did attempt this).

Brown and Levinson proposed five superstrategies (general orientations to face) that are systematically related to the degree of face threat. A rational actor - a "Model Person" (Brown and Levinson 1987) - will select an appropriate superstrategy to counterbalance the expected face threat. In general, an actor would not select a strategy associated with a greater risk of face threat for an act of less risk (as a sort of insurance policy), since the FTA might be assumed to be greater than it is. This would be counter-productive because it is the speaker's "intention to minimize rather than overestimate the threat to the hearer's face" (1987: 74). The individual superstrategies are briefly outlined below (the first superstrategy is associated with lowest face threat, and the last with the most).

1) Bald on record: The FTA is performed "in the most direct, clear, unambiguous and concise way possible" (Brown and Levinson 1987: 69); in other words, in accordance with Grice's Maxims (1975). No attempt is made to acknowledge the hearer's face wants. This strategy is typically used in emergency situations (e.g. shouting "Get out" when a house is on fire), when the face threat is very small (e.g. "Come in" said in response to a knock at the door), and when the speaker has great power over the hearer (e.g. "Stop complaining" said by a parent to a child). 
A final draft of: Culpeper, Jonathan (2011) Politeness and impoliteness. In: Karin Aijmer and Gisle Andersen (eds.)

Sociopragmatics, Volume 5 of Handbooks of Pragmatics edited by Wolfram Bublitz, Andreas H. Jucker and Klaus P. Schneider. Berlin: Mouton de Gruyter, 391-436. This is the final draft submitted, but it may have very minor errors and infelicities.

2) Positive politeness: The use of strategies designed to redress the addressee's positive face wants. The speaker indicates that in general they want to maintain some of the hearer's positive face wants, by, for example, treating the hearer as a member of the same group or by expressing liking for the hearer's personality. The sphere of relevant redress is not restricted to the imposition incurred in the FTA itself. The idea is that the general appreciation of the hearer's wants will serve to counterbalance the specific imposition. It is a sugaring of the pill technique. The expression of positive politeness as a motivated strategy of face threat redress is marked by exaggeration. A general spin-off of positive politeness techniques is that they act as "a kind of social accelerator" (1987: 103), since in using them one indicates a wish to be closer to the addressee.

3) Negative politeness: The use of strategies designed to redress the addressee's negative face wants. The speaker indicates respect for the hearer's face wants and the wish not to interfere with the hearer's freedom of action. Negative politeness is avoidance-based and characterised by:

self-effacement, formality and restraint, with attention to very restricted aspects of H's self-image, centring on his want to be unimpeded. Face-threatening acts are redressed with apologies for interfering or transgressing, with linguistic and nonlinguistic deference, with hedges on the illocutionary force of the act, with impersonalizing mechanisms (such as passives) that distance $\mathrm{S}$ and $\mathrm{H}$ from the act, and with other softening mechanisms that give the addressee an "out", a facesaving line of escape permitting him to feel that his response is not coerced. (1987: 70)

In contrast with positive politeness, negative politeness focuses on the redress of the particular face threat caused by an act. It is a softening of the blow technique. A further contrast is that a spin-off of negative politeness techniques is that it increases social distance, it acts as a "social brake".

4) Off-record: The FTA is performed in such a way that "there is more than one unambiguously attributable intention so that the actor cannot be held to have committed himself to one particular intent" (Brown and Levinson 1987: 69). In other words, it is performed by means of an implicature (Grice 1975). The speaker's face threatening intention can be worked out by means of an inference triggered by the flouting of a maxim. Such implicatures may be denied. For example, "I'm thirsty", said with the goal of getting a cup of tea, flouts the Maxim of Relation (Grice 1975). In a suitable context the hearer may be able to infer that the speaker is asking for a cup of tea, but, if challenged, the speaker could always deny this.

5) Withhold the FTA: The speaker actively refrains from performing the FTA. As Craig et al. (1986: 442) point out, "an option every communicator has is not to talk".

Both positive and negative politeness strategies require "redressive action", that is to say, action that is taken in order to "give face" to the hearer in an attempt to counterbalance the expected face damage of the FTA. Such redressive action need not be verbal: giving a box of chocolates or holding a submissive posture could be positive and negative politeness strategies respectively. But much of Brown and Levinson's work is devoted to the linguistic realisations for positive and negative politeness. Each output strategy is a means of satisfying the strategic ends 
of a superstrategy. The output strategies given by Brown and Levinson (1987: 101-211) are listed below, each with an example I have constructed.

\section{Positive Politeness Output Strategies:}

- Notice, attend to Hearer (H) - "You've had your hair cut."

- Exaggerate (interest, approval, sympathy with H) - "That was so awful, my heart bled for you."

- Intensify interest to $\mathrm{H}$ (exaggerate facts, tell stories in present tense) - "I open the door, guess what I see? A sea of mess."

- Use in-group identity markers (in-group address forms, dialect, jargon, slang, ellipsis) - "Liz, my friend, come here."

- Seek agreement (select a safe topic on which agreement is expected) - "Nice weather today."

- Avoid disagreement (token agreement, white lies, hedging opinions) - "Yes, it's kind of nice."

- Presuppose/raise/assert common ground (small talk, shift deictic centre from S to H, presuppose H's knowledge, wants, attitudes) - "I know how desperate you are to go."

- Joke (utilise shared knowledge, put H "at ease") - "So you're free to do me a favour tomorrow." (said to an obviously busy individual)

- Assert or presuppose S's knowledge of and concern for H's wants - "I know you want to help, I've got a job you can do."

- Offer, promise - "Come over for dinner tomorrow."

- Be optimistic - "You don't mind if I borrow your computer?"

- Include both $\mathrm{S}$ and $\mathrm{H}$ in the activity - "Let's have a drink."

- Give (or ask for) reasons - "The sun is shining. Shall we do the garden?"

- Assume or assert reciprocity - "It's your turn to make the tea. It would do us both good."

- Give gifts to H (goods, sympathy, understanding, cooperation) - "I've recommended you to the boss."

Negative Politeness Output Strategies:

- Be conventionally indirect - "Can you please pass the salt."

- Question, hedge - "Actually, I wondered, if you could help?"

- Be pessimistic (use the subjunctive, negative, and remote-possibility markers) - "I don't suppose there would be any chance of a cup of tea?"

- Minimise the imposition - "Could I borrow your pen for a second?"

- Give deference - "I've been a real fool, could you help me out?"

- Apologise - "I don't want to trouble you, but..."

- Impersonalise S and H - "It would be much appreciated, if this were done."

- State the FTA as a general rule - "Late comers will not be served."

- Nominalise - "Your failure to appear did not make a favourable impression."

- Go on-record as incurring a debt, or as not indebting H - "I'd be forever grateful, if you'd help."

\subsubsection{Application and critical assessment}

Leech (1983b and 1992) demonstrated how his 1983a model might be applied, in the one case to literary prose and in the other to a play, but applications of the entire model have been virtually 
A final draft of: Culpeper, Jonathan (2011) Politeness and impoliteness. In: Karin Aijmer and Gisle Andersen (eds.)

Sociopragmatics, Volume 5 of Handbooks of Pragmatics edited by Wolfram Bublitz, Andreas H. Jucker and Klaus P. Schneider.

Berlin: Mouton de Gruyter, 391-436. This is the final draft submitted, but it may have very minor errors and infelicities.

non-existent (though see Brookins 2010). Instead, specific aspects of his model, such as his treatment of irony or banter, have fed into the development of new models, and, more generally, his work has had an impact on theoretical discussions. As far as specific criticisms, the most frequent are twofold. One is that he offers little guidance on the application of the maxims, with the exception of the Tact maxim. Do the sociological variables (e.g. power, social distance) apply equally to the other maxims? The other is that the list of maxims is open-ended. What is to stop the proliferation of maxims? Regarding the latter criticism, this is one that Brown and Levinson (1987: 4-5) themselves make of Leech, arguing that Leech's model is too unconstrained to permit counterexamples and claiming their own model to be more parsimonious. Leech's (pers. com.) riposte includes the observation that Brown and Levinson's model is equally subject to proliferation: their lists of linguistic output strategies are open-ended.

Turning to Brown and Levinson (1987), I will review each of the aspects of the model noted in the previous section. Recent discussion has focused on the precise definition of "face" (see in particular Bargiela-Chiappini 2003; Arundale 2006), and much of this has been a reaction to Brown and Levinson's (1987) idea that face can be described in terms of universal individualistic psychological "wants". Brown and Levinson (1987: 61) claim that their notion of face is "derived from that of Goffman and from the English folk term". However, with Goffman, it is not just the positive values that you yourself want, but what you can claim about yourself from what others assume about you. How you feel about yourself is dependent on how others feel about you, and so when you lose face you feel bad about how you are seen in other people's eyes. This social interdependence has been stripped out of Brown and Levinson's reductive definition. Positive face is about what you as an individual find positive; negative face is about not imposing upon you as an individual. But this seems to ignore cases where the positive attributes apply to a group of people (e.g. a winning team), or where an imposition on yourself is not the main concern, but rather it is how you stand in relation to a group (e.g. whether you are afforded the respect associated with your position in the team). From a cultural perspective, researchers have argued that Brown and Levinson's emphasis on individualism is a reflection of Anglo-Saxon culture, and not at all a universal feature. Matsumoto (1988), for example, points out that Japanese culture stresses the group more than the individual (see also Ide 1989; Gu 1990; Mao 1994; Nwoye 1992; Wierzbicka 2003 [1991], for similar points):

What is of paramount concern to a Japanese is not his/her own territory, but the position in relation to the others in the group and his/her acceptance by those others. Loss of Face is associated with the perception by others that one has not comprehended and acknowledged the structure and hierarchy of the group. [...] A Japanese generally must understand where s/he stands in relation to other members of the group or society, and must acknowledge his/her dependence on the others. Acknowledgement and maintenance of the relative position of others, rather than preservation of an individual's proper territory, governs all social interaction. (Matsumoto 1988: 405)

Ide (e.g. 1989, 1993) argues that for some cultures politeness is not simply a matter of the individual's strategic choice in redressing FTAs (something which relates to "volition"), but a matter of working out your position in a group and the social norms and acting accordingly. The latter Ide refers to as "wakimae", a notion that bears strong similarities with Watts's $(1989,2003)$ notion of "politic behaviour", which I will discuss later. 
A final draft of: Culpeper, Jonathan (2011) Politeness and impoliteness. In: Karin Aijmer and Gisle Andersen (eds.)

Sociopragmatics, Volume 5 of Handbooks of Pragmatics edited by Wolfram Bublitz, Andreas H. Jucker and Klaus P. Schneider.

Berlin: Mouton de Gruyter, 391-436. This is the final draft submitted, but it may have very minor errors and infelicities.

As I observed in the previous section, Brown and Levinson's (1987) work is limited to acts that threaten face, and facework (politeness work) that attempts to redress those threatening acts. What about acts that simply enhance face? An important merit of Leech's Politeness Principle is that it is not confined to the management of potentially "impolite" acts (i.e. FTAs), such as asking somebody to do something for you, but also involves potentially "polite" acts (Leech 1983a: 83) (or face enhancing acts), such as a compliment out of the blue. Leech's Politeness Principle allows for the minimisation of impolite beliefs and the maximisation of polite beliefs. This helps account for why, returning to an earlier example, the direct command "Have a drink" at a social occasion, which would appear to be impolite in brusquely restricting the hearer's freedom of action, in fact maximises a polite belief such as that the hearer would like and would benefit from a drink but is too polite to just take one. And what about acts that simply attack face - threats, insults, put-downs, sarcasm, mimicry and so on? This is no problem for Leech, but lies outside the scope of Brown and Levinson (they did not follow up Goffman's 1967: 24-6 comments on "aggressive facework"). Clearly, politeness is not the issue here but rather "impoliteness", an area I will attend to in section 3. Recent "relational" approaches to politeness, to be reviewed in section 2.3.2, locate potentially polite behaviours within a framework that encompasses all kinds of facework.

Facework is generally more complex than Brown and Levinson's (1987) model suggests. There is no neat separation between positive and negative facework, as several researchers have pointed out (see the discussion of mixed output strategies below). An interruption, for example, imposes on the other and thus may seem typical of negative face threat, but the interruption may also imply that the person who interrupted did not care to hear what the target was saying (i.e. they signal that it has little value for them), which would be typical of positive face threat. In my view, whilst an act may primarily have implications for one kind of face, it will often have secondary implications for other kinds. Furthermore, many of the acts that Brown and Levinson list as primarily threatening the hearer's face can have ramifications for the speaker's face. Orders, threats, criticisms and contradictions carry potentially unfavourable, and hence self face threatening, attributions (e.g. authoritarianism and hostility), that may merit facework attention. Coupland et al. (1988) provide a good illustration of this. They studied politeness phenomena in nurses' talk to institutionalised elderly people, and, in particular, attempts to redress the face threat involved in requesting that medicines be taken. Facework apparently directed at the positive face of the patients, such as the in-group identity markers "my darling, Edith, love" (1988: 259), is described by the authors as "mere verbalisations" (1988: 260). Facework apparently directed at the negative face of the patients, such as attempts to minimise the imposition of a drink by referring to it as "little" (1988: 261), is described as "more rather than less likely to impose and threaten face" (1988: 261), since it trivialises the imposition. Coupland et al. conclude that facework was partly designed to maintain the face of the nurses themselves. By producing the trappings of politeness the nurses could redress actions that threaten their face "both as a caring individual and as a competent professional" (1988: 260-261).

Brown and Levinson's (1987) theory of the mutual vulnerability of face is insufficient as an explanation of cooperation in facework. People are actively involved in maintaining and enhancing their own faces, and not merely hoping for reciprocal facework. Also, self-interest motivates cooperative behaviour for a number of reasons, not just mutual vulnerability. For example, cooperative social behaviour can promote an image of friendliness, kindness, helpfulness, etc., and this may well be an important identity claim of the self. 
A final draft of: Culpeper, Jonathan (2011) Politeness and impoliteness. In: Karin Aijmer and Gisle Andersen (eds.) Sociopragmatics, Volume 5 of Handbooks of Pragmatics edited by Wolfram Bublitz, Andreas H. Jucker and Klaus P. Schneider. Berlin: Mouton de Gruyter, 391-436. This is the final draft submitted, but it may have very minor errors and infelicities.

Note that Brown and Levinson's book was published in a sociolinguistics series, exemplifying interactional sociolinguistics. It is no surprise then that the methodological flavour of the dominant sociolinguistics paradigm, that of Labov, with its emphasis on quantification, affected subsequent politeness studies. Numerous researchers began administering questionnaires or Discourse Completion Tasks (favourite though not the only methodologies) to quantify the kind of politeness strategies used by people of different relative power, social distance and so on (see Spencer-Oatey 1996, for many references). Research has strongly supported Brown and Levinson's claims for the power variable: the more relatively powerful speaker being associated with less politeness (e.g. Falbo and Peplau 1980; Baxter 1984; Holtgraves 1986; Brown and Gilman 1989; Holtgraves and Yang 1990; Lim and Bowers 1991; Leichty and Applegate 1991). Research has also generally supported claims about the rank variable: the greater imposition being associated with more politeness (Cody et al. 1981; Lustig and King 1980; Brown and Gilman 1989; Holtgraves and Yang 1992). However, evidence for claims about the distance variable, that politeness increases with distance, has been inconsistent. Baxter (1984) and Brown and Gilman (1989) found that more politeness was used in closer relationships. However, the basis of these studies is now being questioned. Spencer-Oatey (1996) demonstrated that researchers varied widely in what is understood by power or social distance. In fact, these variables were sometimes subsuming other independent variables. Baxter (1984), for example, showed that affect (i.e. whether there is liking or disliking between participants) was getting muddled up with social distance, but in fact is an independent variable. It is also worth noting here that Wolfson's (1988) "bulge theory" of social distance flies in the face of Brown and Levinson's claims. According to bulge theory, our responses to the extremes on the social scale, strangers and intimates, are similar; it is acquaintances, co-workers and casual friends who are different, because their social relationship is less certain and thus requires more negotiation. In politeness terms, a graph with increasing degrees of politeness on the $y$ axis and of social distance on the $x$ axis would have a bell curve and not a straight positive linear relationship, as predicted by Brown and Levinson. Furthermore, Brown and Levinson concede that they "underplay the influence of other factors" (1987: 12) in determining the seriousness of face threat. For example, the rights and obligations, the presence of a third party, formality or mood may be important. Regarding combinations of variables, Brown and Levinson assume that the effects of power, distance and rank on the perceived degree of face threat are independent of each other and additive; that is to say, each variable would have the same effect regardless of the other variables. This understanding is implicit in their formula for the calculation of face threat. However, there is some empirical evidence which suggests that the combination of these variables is not that simple. For example, Holtgraves and Yang (1990) found a relationship between power and distance such that when the speaker and hearer differed in power, distance had little effect.

Brown and Levinson admit that they "may have been in error to set up the three superstrategies, positive politeness, negative politeness, and off record, as ranked unidimensionally to achieve mutual exclusivity" (1987: 18), but, they argue that there is an "absence of definitive evidence" that they "got the ranking wrong" (1987: 20), and, as mentioned above, resist the idea that strategies can be mixed (for example, positive politeness markers occurring in negative politeness strategies such as indirect requests) (1987: 17-20). However, a number of researchers have challenged that ranking. Blum-Kulka (1985) suggests that off-record strategies could be less polite than negative politeness strategies, since it is impolite to require a superior to calculate the force of an off-record request. Baxter (1984) suggests that positive politeness may 
A final draft of: Culpeper, Jonathan (2011) Politeness and impoliteness. In: Karin Aijmer and Gisle Andersen (eds.) Sociopragmatics, Volume 5 of Handbooks of Pragmatics edited by Wolfram Bublitz, Andreas H. Jucker and Klaus P. Schneider. Berlin: Mouton de Gruyter, 391-436. This is the final draft submitted, but it may have very minor errors and infelicities.

presuppose negative politeness and should therefore occupy a higher position in the hierarchy. Moreover, several researchers (e.g. Scollon and Scollon 1981; Craig et al 1986; Tracy 1990; Lim and Bowers 1991) argue that, because positive and negative politeness are different in type, they cannot be ranked unidimensionally. For example, Lim and Bowers (1991) argue that strong threats to positive face are not usually counterbalanced by negative facework. They give the following example, "I'm sorry to say this. I know that I don't have any right to criticise you, but you did a poor job". The negative politeness strategies here - the apology and assertion of the hearer's rights to immunity from imposition - do not ameliorate the criticism. Brown and Gilman's (1989) solution was to have a single category of redress in which acts of positive or negative politeness may be mixed, but need not be. Craig et al (1986: 452-3) claim that it is possible for a strategy to involve both negative and positive politeness. An example they give from their data is "Do me a favour", which they argue is a kind of apology in Brown and Levinson's terms (in so far as there is an admission that the 'favour' will impinge on the other) (negative politeness), but also a kind of reciprocal doing of favours (positive politeness). In general it is difficult to assess the evidence, since it is not clear what the underlying politeness dimension linked to the superstrategies actually is.

Like the superstrategies, the output strategies for positive and negative politeness are not linked to any clear underlying dimension of politeness. As Shimanoff (1977) notes, sometimes they are defined functionally (e.g. "Be pessimistic") and sometimes linguistically (e.g. "Question, hedge"). Thus, the status of each strategy and how it relates to the other strategies is not clear. Craig et al. (1986) pose a number of pertinent questions related to this issue. Can individual output strategies be scaled? Are all negative politeness strategies more redressive than any positive politeness strategy? Which output strategy will one select to serve a particular superstrategy? Furthermore, the output strategies can perform other functions apart from face redress. For example, they can be used, Brown and Levinson admit, as a social "accelerator" or "brake". Neither are they mutually exclusive. For example, Craig et al. (1986: 446) point out that "certain verbal hedges (negative politeness strategy 2; 'I wonder whether' or 'I was wondering') also appear to count as conventional indirectness (negative politeness strategy 1)". Regarding the relationship between the output strategies and politeness, one issue is how politeness is affected by the quantity of strategies. Brown and Gilman (1989) assess the amount of redress in terms of the number of "codable" output strategies, claiming that incidental remarks made by Brown and Levinson justify this approach (e.g. "In general, the more effort $\mathrm{S}$ expends in face maintaining linguistic behaviour, the more $\mathrm{S}$ communicates his sincere desire that H's face wants be satisfied", 1987: 93). Elsewhere, however, Brown and Levinson (1987: 22) explicitly attack this approach: "politeness is implicated by the semantic structure of the whole utterance, not communicated by 'markers' or 'mitigators' in a simple signalling fashion which can be quantified". The point here is that politeness is not just determined by a particular strategy. It is determined by a particular strategy in a particular context and the participants' particular assessment of the whole. One final point to mention regarding the output strategies, though it is not one mentioned in the literature, is that Brown and Levinson pay very little attention to prosodic, paralinguistic or non-verbal resources for conveying politeness. In a suitable context, a smile could be a means of attending to somebody else's face; or an intonation contour might be crucial in interpreting the "politeness" of a speech act (see, for example, Wichmann 2004 on please-requests). This deficit is in fact a general one across the entire literature. The single exception of note is Arndt and Janney (1987), who argue that 'utterances become "meaningful" by which we mean interpretable - only through the interaction of verbal, prosodic, and kinesic 
A final draft of: Culpeper, Jonathan (2011) Politeness and impoliteness. In: Karin Aijmer and Gisle Andersen (eds.)

Sociopragmatics, Volume 5 of Handbooks of Pragmatics edited by Wolfram Bublitz, Andreas H. Jucker and Klaus P. Schneider.

Berlin: Mouton de Gruyter, 391-436. This is the final draft submitted, but it may have very minor errors and infelicities.

actions in context' (1987: 248). They argue that people, as opposed to social situations and their norms of appropriacy, are the locus of politeness, and that we should "focus on cross-modal emotive behaviour as a means by which politeness is negotiated” (1987: 377).

\subsection{Second-wave approaches to politeness}

\subsubsection{Rejection}

In the previous section, we saw how numerous studies, particularly dating from the 1980s and 1990s, have addressed particular aspects of Brown and Levinson's (1987) politeness theory. By the 2000s, the tide of criticism had reached the point where the very foundations of Brown and Levinson's model were being challenged. The landmark publication initiating the second wave is probably Gino Eelen's A Critique of Politeness Theories (2001), though some foundations were laid in Watts et al. (2005b [1992]). It should be noted here that some of these critical challenges simply reflect the fact that thinking about how communication and social and interpersonal interaction works had moved on since the 1970s, when the seeds of Brown and Levinson (1987) and Leech (1983a) were sown. ${ }^{1}$

Let us review some of the fundamental criticisms. With respect to Brown and Levinson's (1987) politeness theory, some are:

(1) Ignoring the lay person's conception of politeness, as revealed through their use of the terms polite and politeness, and instead postulating a facework theory as a theory of politeness;

(2) Claiming to be universal (a particular issue with regard to their conception of "face" applied across diverse cultures);

(3) Basing the politeness model on an inadequate pragmatic model, which is biased towards the speaker and the production of language and which fails to account for key ways in which politeness is understood; and

(4) Failing to articulate an adequate conception of context, despite the key importance of context in judgments of politeness.

Further criticisms are given in Eelen (2001: 245-6), one of which is the failure to adequately deal with impoliteness, something that I shall attend to in section 3. The following paragraphs will expand on each of the above four points in turn.

We have already seen in section 2.1 how Watts (e.g. 1992, 2003; Watts et al. 2005b) led criticisms of the classic pragmatics-based politeness theories, arguing that they articulated a pseudo-scientific theory of particular social behaviours, labelling them politeness (so-called politeness2), whilst ignoring the lay person's conception of politeness as revealed through their use of the terms polite and politeness to refer to particular social behaviours (so-called politeness1). This criticism strikes at the epistemological and methodological foundations of politeness, as it concerns where our understanding of politeness comes from, the observers or the participants. Similar criticisms have been made of other areas of social science. Broadly speaking, this particular critical thrust reflects a shift in emphasis, at least in some paradigms, from "etic" approaches to an "emic" ones, to use the terminology coined by Kenneth Pike (1967 [1954]). A particular characteristic of politeness1 approaches is that notions of politeness are not taken as given, but are assumed to be subject to dispute, to be negotiated - and indeed emerge in interaction. In other words, politeness is discursive. I will discuss the discursive approach to 
A final draft of: Culpeper, Jonathan (2011) Politeness and impoliteness. In: Karin Aijmer and Gisle Andersen (eds.) Sociopragmatics, Volume 5 of Handbooks of Pragmatics edited by Wolfram Bublitz, Andreas H. Jucker and Klaus P. Schneider. Berlin: Mouton de Gruyter, 391-436. This is the final draft submitted, but it may have very minor errors and infelicities.

politeness in section 2.3.2. It should be noted that Watts and his colleagues are not dismissing politeness 2 approaches. They are mainly concerned with politeness 2 approaches masquerading as politeness 1 approaches, or vacillation between the two. Consequently, they argue for distinct terminology and definitions, as well as careful monitoring (see also, Eelen 2001: 30-32). Of course, being explicit about the basis of one's approach, notions and claims makes for good social science. This is not to say that it is easy: all politeness 2 approaches encompass at least some politeness 1 notions - if they did not, a manual on car mechanics would have a more or less equal claim to be a textbook on politeness.

Brown and Levinson have received much criticism for proposing that their model is universal. In this respect, one might note that the title of their book is Politeness: Some Universals in Language Usage. However, it is not as if Brown and Levinson (1987) were unaware of cultural differences. In their view, "any comparative social theory must be at once based on universal principles and yet have culture-internal application" (1987:242). If we throw out universal concepts or more radically any kind of generalization, how can we compare the politeness of one culture with that of another, if each is defined solely within its own terms? It would be the equivalent of comparing apples with oranges and concluding that they are different; whereas applying dimensions of variation (e.g. the absence/presence of seeds, edibility, sweetness) gives us a handle on the differences. In fact, this is one of the potential weaknesses of the politeness 1 approaches: how do we compare politeness in one culture with that of another, if we base our approach solely on members' constructs? Having said all this, it cannot be denied that Brown and Levinson's particular "universal principles" turn out not to be so universal. As I noted in the previous section, much criticism has focused on their definition of face, which they claimed to be universal (e.g. 1987: 244). Its basis in the psychological "wants" of individuals and construction as two components, positive and negative, has led to difficulties when applied across various cultures. Recent approaches to politeness have in fact tended to shift back towards Goffman (e.g. Arundale 2006), and/or considerably elaborate and supplement the notion of face, as we will see is the case for Spencer-Oatey's (e.g. 2000) framework. One final point to mention on the topic of universality is that Leech's (1983a) politeness framework is sometimes lumped together with Brown and Levinson (1987) and criticised for being universalist (see for example, Wierzbicka 2003 [1991]). Whilst Leech (1983a) does concentrate on the elaboration of the Tact maxim, which is perhaps stereotypical of British culture, it is a gross misreading to claim that that work argues for universality. Such claims were part of the motivation for writing Leech (2007), a publication in which he repudiates such claims and also takes the opportunity to update his framework. He spells out his position thus:

It is premature to talk of universals of politeness, but my position is as follows. Probably the scales of value in [section] 5.5 above are very widespread in human societies, but their interpretation differs from society to society, just as their encoding differs from language to language. I suggest this is the basis on which a well-founded cross-cultural pragmatic research could proceed. The question to ask is: given these scales of value, what socio-cultural variants of them are found in particular cultures, and what pragmatic linguistic forms of language are used to encode these variants? (2007: 200-201)

Classic politeness theories are built on classic Speech act theory (e.g. Austin 1962; Searle 1969) and Gricean implicature (Grice 1975), which, separately or together, do not offer an adequate account of communication, or of politeness in particular. Speech act theory is discussed 
A final draft of: Culpeper, Jonathan (2011) Politeness and impoliteness. In: Karin Aijmer and Gisle Andersen (eds.) Sociopragmatics, Volume 5 of Handbooks of Pragmatics edited by Wolfram Bublitz, Andreas H. Jucker and Klaus P. Schneider. Berlin: Mouton de Gruyter, 391-436. This is the final draft submitted, but it may have very minor errors and infelicities.

in relation to single short utterances with single functions, single speakers and single addressees. This ignores the multi-functionality and complexity of discourse situations (see, for example, Thomas 1995: 195-204), and the fact that speech acts are often constructed over a number of turns (see, for example, Geis 1995). Brown and Levinson (1987: 10) recognise that the adoption of speech act theory as a basis for their model has not been ideal:

speech act theory forces a sentence-based, speaker-oriented mode of analysis, requiring attribution of speech act categories where our own thesis requires that utterances are often equivocal in force.

The sort of decontextualised speech acts they use do not reflect the indeterminacies of utterances and the face threatening ramifications they may have for any of the participants in a particular speech event. Brown and Levinson's work includes no extended examples. Gricean implicature underpins the traditional approaches to politeness. Brown and Levinson (e.g. 1987: 95) postulate that deviations from the maxims coupled with inferential work result in the intended message, which can include a politeness motive. In other words, politeness involves recovering a particularised implicature concerning the speaker's polite intentions (see also Brown 1995). Broadly speaking, Leech (1983a) pursues the same line. Central, then, is the idea that intentions exist a priori in the minds of speakers and that it is the recovery of a speaker's "polite" intentions by hearers that leads to the understanding of politeness. But the Gricean (e.g. 1957, 1969, 1975) model of communication has been challenged in various respects, including its emphasis on the reflexivity of (communicative) intentions, the relative neglect of conventionality and the fact that it ignores collective or "we-intentions" (Haugh 2008: 101, where many supporting references can be found). Even more problematic for the classic theories of politeness is that politeness does not always rely on the recognition of the speaker's intentions. Politeness can also be conveyed without deviations from the Cooperative Principle. Merely saying "good morning" to my colleague at the beginning of the working day may be considered "polite", but this does not involve a deviation from the Cooperative Principle triggering the recovery of the speaker's intention - it is more a case of performing a routine expected by the hearer, given the social norms. A number of researchers have accounted for the fact that politeness can be expected, normal, not noticed and thus not a deviation from the Cooperative Principle (e.g. Escandell-Vidal 1998; Jary 1998; Terkourafi 2001; Watts 2003). This kind of politeness is labelled "anticipated politeness" by Fraser (1999, cited in Terkourafi 2001). The distinction between anticipated politeness and inferred politeness is elaborated by Haugh (2003) (see also Terkourafi 2001: 1217). In a nutshell, "politeness is anticipated when the behaviour giving rise to politeness is expected, while it is inferred when the behaviour giving rise to politeness is not expected" (Haugh 2003: 400).

Gricean implicature also underpins the notion of directness (cf. Searle 1975). The main dimension along which Brown and Levinson's (1987) super-strategies for performing politeness are ordered is directness, defined in terms of complying with or deviating from Grice's Cooperative Principle. Thus, at one end we have bald on record and at the other end we have off record (or even avoiding the face threatening act altogether), and in between we have negative and positive politeness. Leech's (1983a: 108) comments on the relationship between politeness and indirectness are frequently cited: indirect utterances, such as 'Could you possibly answer the phone', tend to be more polite because they increase optionality for the hearer, whilst decreasing illocutionary force (cf. Leech 1983a: 108). However, Leech's account is more nuanced, as he 
A final draft of: Culpeper, Jonathan (2011) Politeness and impoliteness. In: Karin Aijmer and Gisle Andersen (eds.) Sociopragmatics, Volume 5 of Handbooks of Pragmatics edited by Wolfram Bublitz, Andreas H. Jucker and Klaus P. Schneider. Berlin: Mouton de Gruyter, 391-436. This is the final draft submitted, but it may have very minor errors and infelicities.

also points out that indirectness might increase impoliteness when expressing "impolite beliefs". He comments "because 'You have something to declare' is an impolite belief, the more indirect kinds of question [e.g. 'Haven't you something to declare'] are progressively more impolite, more threatening, than the ordinary yes-no question" (1983a: 171). Nevertheless, Blum-Kulka's (e.g. 1987), work on requests in various cultures, suggests a different picture. The politest way of making a request is by "appearing to be indirect without burdening the hearer with the actual cost of true directness" (1987: 143-144). This can be achieved by using conventionally indirect strategies, which short-circuit the necessary inferencing to arrive at the illocutionary point of the utterance. But whilst the argument is neat, this does not work for all cultures. Wierzbicka ([1991] 2003: 34) reports that "in Polish, politeness is not linked with an avoidance of imperative, and with the use of [conventionally indirect] interrogative devices, as it is in English", and that the "flat imperative" "constitutes one of the milder, softer options in issuing directives" (2003:36). The point is that the interpretation of directness varies according to culture; more directness is not always interpreted as less politeness (particularly, it seems, in less individualistic cultures) (see also Field 1998 on directives in a native American culture). More fundamentally, the notion of directness, largely shaped by Searle's (1975) classic work on indirect speech acts, is highly problematic. There is little agreement on the status of direct/indirect speech acts, how indirect speech acts work or where to draw the line between the three usual categories of directness direct, conventionally direct and non-conventionally direct (see Aijmer 1996: 126-8, for a brief overview of some of the issues). A particular limitation is that key interpersonal information, such as relative power, social distance, and so on, is missing from Searle's account. This information alone can trigger, for example, the perception that somebody is making a request or order, circumventing any Gricean inferencing. Holtgraves (1994), for instance, found that knowing that a speaker was of high status was enough to prime a directive interpretation, in advance of any remark having been actually made (see also Ervin-Tripp et al. 1987 and Gibbs 1981, for the general importance of social context in speech act interpretation).

This leads us to our final consideration in this section, namely, the fact that context is inadequately handled in the classic politeness models, being reduced to a handful of social variables which do not reflect the complexity of real world interactive events (for an excellent illustration of this, see Turner's 2003 discussion of power). The sheer complexity of context is daunting, encompassing not only aspects of the world relevant to communication, but also their cognitive representation, their emergence in dynamic discourse, different participant perspectives on them and their negotiation in discourse, and so on. Myers (1991: 44-5), for example, notes that the values for all variables are not given, but are constructed in interaction. For each variable "there is not one value, but a tension between at least two interpretations of the situation" (Myers 1991: 44). To be fair to Brown and Levinson, they did acknowledge part of the problem, stating that values on their variables 'are not intended as sociologists' ratings of actual power, distance, etc., but only as actors' assumptions of such ratings, assumed to be mutually assumed, at least within certain limits' (1987: 74-6) [original emphasis]. But they did not back this up with a suitable methodology (one which is more qualitative in nature and thus able to handle the complexity), and subsequent researchers often chose to ignore it. Research on social context has now moved on, leading to paradigm shifts across the social sciences. With respect to the development of sociolinguistics, we have seen a (at least partial) shift away from the Labovian variationist model. Research on context was given a particular boost by the papers published in Duranti and Goodwin (1992). I noted in section 2.2.2 that power had been found to be particularly important with respect to politeness. The focus on politeness and power has 
continued in the literature, fuelled by significant developments in the way power is conceptualised (cf. Bourdieu 1991; Fairclough 1989). Power and politeness are the focal points of two recent monographs, Holmes and Stubbe (2003) and Locher (2004), and various articles (e.g. Harris 2003; Mullany 2004; Tiisala 2004).

\subsubsection{Replacement}

Many specific improvements to the classic politeness models have been proposed, as have a number of new models that can claim to be radically different at least in some respects. I will focus on the latter, and discuss them under three headings: (1) discursive, (2) relational, and (3) frame-based. Two points need to be stressed. One is that I use these headings to group work that has distinctive similarities, but I fully acknowledge that there are also some differences. The other is that some works claim a stake in more than one approach; the groups are not mutually exclusive.

\section{Discursive}

A particularly noteworthy line of work is sometimes referred to as "post-modern" or "discursive" (e.g. Eelen 2001; Locher 2004, 2006; Locher and Watts 2005; Mills 2003; Watts 2003, 2005a [1991]; Watts et al. 2005b [1992] $]^{2}$ ). As a far as the label post-modern signals a concern with cultural and individual relativism and a dislike of universalising generalisations, it is accurate, but it brings some unwanted baggage with it, and so I will deploy the label discursive. Indeed, a key feature of all this work is that it emphasises that the very definitions of politeness itself are subject to discursive struggle. As one might guess from this, discursive work leans towards politeness1, and indeed shares some of its characteristics (see, for example, the discussion of politeness 1 in Eelen 2001:32-43). Although works apparently belonging to the discursive approach vary somewhat, their characteristics typically include:

- the claim that there is no one meaning of the term "politeness" but it is a site of discursive struggle;

- the centrality of the perspective of participants;

- an emphasis on situated and emergent meanings rather than pre-defined meanings;

- the claim that politeness is evaluative in character (that it is used in judgements of people's behaviours);

- an emphasis on context;

- the claim that politeness is intimately connected with social norms, which offer a grasp on the notion of appropriateness (note here the connection with the socio-cultural view of politeness discussed in section 2.2);

- the reduction of the role of intention in communication (it is rejected, or at least weakened or re-conceptualised);

- a focus on the micro, not the macro; and

- a preference for qualitative methods of analysis as opposed to quantitative.

Most of these characteristics are also typical of discursive approaches generally. For example, of particular note is the development of the discursive approach in social psychology, spurred on especially by Derek Edwards and Jonathan Potter (e.g. 1992). Discursive psychology similarly 
A final draft of: Culpeper, Jonathan (2011) Politeness and impoliteness. In: Karin Aijmer and Gisle Andersen (eds.) Sociopragmatics, Volume 5 of Handbooks of Pragmatics edited by Wolfram Bublitz, Andreas H. Jucker and Klaus P. Schneider. Berlin: Mouton de Gruyter, 391-436. This is the final draft submitted, but it may have very minor errors and infelicities.

emphasises emergent and contingent interactional meanings, is anti-cognitivist, and uses qualitative methods.

Creating a "theory" of politeness seems not to be the objective for the discursive politeness approach (cf. Watts 2005b: xlii). A consequence of focussing on the dynamic and situated characteristics of politeness is that politeness is declared not to be a predictive theory (Watts 2003: 25), or, apparently, even a post-hoc descriptive one (Watts 2003: 142). As Terkourafi comments (2005a: 245): "What we are then left with are minute descriptions of individual encounters, but these do not in any way add up to an explanatory theory of the phenomena under study". Furthermore, if "the analyst cannot legitimately attribute meaning, one wonders what, then, does constitute a legitimate role for the analyst" (Holmes 2005: 115, original emphasis; Haugh 2007b: 297 makes a similar point). However, to be fair to the key practitioners of discursive politeness approach, such as Richard Watts and Miriam Locher, and returning to a point made in the previous section, there is no prohibition on using a conceptual apparatus of the politeness2 kind. For example, Locher (2006: 262; my emphasis) writes that the

discursive approach to politeness stresses that we first of all have to establish the kind of relational work the interactants in question employ to arrive at an understanding of the then-current norms of interaction.

Watts (e.g. 2003) and Locher (e.g. Locher 2004; Locher and Watts 2005) embrace the relational approach, which I shall discuss shortly. The concepts that comprise the relational approaches are second-order. For example, Locher (2006: 256) states that the concept of "politic behaviour" is a second-order term, although she claims that it can be "equalled with appropriateness in lay people's perceptions". Indeed, note that the relational approach need not be pursued discursively. In point of fact, the relational approach taken by Spencer-Oatey (e.g. 2000), offering a powerful second-order descriptive framework for cross-cultural comparisons, would not match all of the discursive characteristics listed above. Furthermore, Watts (e.g. 2003) and Locher (e.g. Locher 2004; Locher and Watts 2005) both embrace the notion of a (cognitive) "frame", a second-order concept, which again I will discuss shortly. In practice then, I have argued that Locher and Watts's work knowingly combines approaches of different orders. What is not so clear is whether the label discursive applies to the whole resulting combination or just the more discursive aspect. In my view, the relational and frame aspects so clearly do not fit discursive characteristics, as listed above, that they could not be considered discursive. In contrast, Haugh (2007b) understands the discursive approach they articulate to embrace relational work, something which then affords him ample opportunity to point out why their approach is incoherent. Whatever the case, as a whole, Locher and Watts's approach is not purely discursive. This may also partly be the reason why some of their apparently discursive politeness analyses do not always seem to pursue the discursive agenda to the full. In the absence of participants deploying and debating explicit evaluations of (im)politeness in the discourse that has taken place, some data for politeness analyses are selected on the basis of claims by the researcher, supported by implicit evidence, that they involve politeness (or rather a weaker claim of "potential politeness"), much in the same way as data analyses of naturally occurring conversation in studies of politeness2. Interestingly, Watts (e.g. 1989, 2003) embraces relevance theory (Sperber and Wilson 1995 ) as an explanatory framework. Mills (2003) also argues, though not uncritically, that relevance theory can make a contribution to the discursive approach (see also Christie 2007: 278279). Given that relevance theory is a "grand" theory of universal application, this would seem a 
A final draft of: Culpeper, Jonathan (2011) Politeness and impoliteness. In: Karin Aijmer and Gisle Andersen (eds.) Sociopragmatics, Volume 5 of Handbooks of Pragmatics edited by Wolfram Bublitz, Andreas H. Jucker and Klaus P. Schneider. Berlin: Mouton de Gruyter, 391-436. This is the final draft submitted, but it may have very minor errors and infelicities.

rather odd move. It has been used to account for politeness by a number of scholars (e.g. Escandell-Vidal 1996; Jary 1998; Christie 2007). In particular, relevance theory can account for the anticipated versus inferred distinction: so few cognitive effects arise from anticipated politeness (behaviour following social norms) that it is not relevant enough to spend inferential effort; but when there are sufficiently large cognitive effects to reward processing effort, inferred politeness can take place. What makes it attractive to scholars pursuing the discursive approach is that it emphasises the hearer and does not have generalised norms of behaviour as a starting point, instead focusing on specific situated behaviours "it provides an extremely powerful interpretive apparatus" (Watts 2003: 212). However, relevance theory has three problems for politeness-related studies. Firstly, the relevance theory account of communication still involves the recognition of speakers' intentions. It does not suit politeness to place a relatively restricted notion of intention at its centre. Secondly, Haugh (2003: 46) points out that the notion of cognitive effects has not been sufficiently characterised:

[T] here is no distinction made between cognitive effects which have 'positive effect " (such as feelings of approval or warmth and so on), and those which have 'negative effect' (such as antagonism or alienation and so on). For example, there is no distinction made between showing that one thinks well of others (which can give rise to politeness), and showing that one thinks badly of others (which can give rise to impoliteness).

Thirdly, no publication has shown how relevance theory can produce effective analyses of stretches of naturally-occurring discourse, a limitation Watts (2003: 212) concedes: "[o]ne major problem with RT is that it rarely, if ever, concerns itself with stretches of natural verbal interaction" (2003:212).

As an antidote to the classic politeness theories, discursive politeness work has been a valuable corrective. In particular, it has drawn attention to the fact that (im)politeness is not inherent in particular forms of language in the sense that a judgement of politeness is solely determined by the usage of particular language, arguing instead that it is a matter of the participants' evaluations of particular forms as (im)polite in context. It has also been influential: indeed, many recent studies have at least some of the characteristics of the discursive approach. However, even the leading politeness discursive work has but some characteristics of a purely discursive approach and not all. So, what might a purely discursive approach to politeness look like? The obvious, well-established methodological approach which emphasises the understandings displayed by participants themselves is Conversation Analysis. Few politeness studies have adopted this approach (but see the notable example of Piirainen-Marsh 2005). Perhaps the reason for this is that Conversation Analysis has nothing to say about politeness itself: we still need to interpret a participant's understanding of politeness as relevant to the theory of politeness with which we as analysts are approaching the data. This point is elaborated in Haugh (2007b). Haugh (2007b) argues that the Conjoint Co-Constituting Model of Communication (Arundale e.g. 1999, 2006) has much to offer as a framework for the study of politeness, "as it is consistent with a conceptualization of (im)politeness as being interactionally achieved in a collaborative, non-summative manner through interaction by participants, whilst carefully avoiding the ontological trap of conflating the analysts' and participants' perspectives" (2007b: 309). Interestingly, this approach encompasses a wider context than the local structures of conversation analysts, including for example aspects of identity and the history of particular identities. Also, in this approach evidence for politeness evaluations involves the analyst not just in looking at explicit comments made by participants, but also at "the reciprocation of concern 
A final draft of: Culpeper, Jonathan (2011) Politeness and impoliteness. In: Karin Aijmer and Gisle Andersen (eds.) Sociopragmatics, Volume 5 of Handbooks of Pragmatics edited by Wolfram Bublitz, Andreas H. Jucker and Klaus P. Schneider. Berlin: Mouton de Gruyter, 391-436. This is the final draft submitted, but it may have very minor errors and infelicities.

evident in the adjacent placement of expressions of concern relevant to the norms invoked in that particular interaction" (2007b:312). The idea of "reciprocation of concern" is an important one, and in fact will be echoed in another framework discussed later in this section. Although the proof of the pudding is in the eating - and we have yet to see the power of this interactional approach in extended analyses of data - it clearly deserves attention.

\section{Relational}

Christie (2005: 4) points out that three of the five articles constituting the very first edition of the Journal of Politeness Research: Language, Behaviour, Culture stress that politeness is some form of "relational work". Whether one uses the term "relational work" (Locher and Watts 2005), "relational practice" (Holmes and Schnurr 2005) or "rapport management" (SpencerOatey 2000, 2005), they have in common a central focus on interpersonal relations, rather than a central focus on the individual performing "politeness" which is then correlated with interpersonal relations as variables. Also, they include impolite behaviour within the scope of relational work, whilst avoiding presenting it as a simple dichotomy with politeness. I will outline Locher and Watts's (e.g. Locher 2004, 2006; Locher and Watts 2005; Watts 2003) framework, and then that of Spencer-Oatey (e.g. 2000, 2005).

Locher and Watts state that "relational work can be understood as equivalent to Halliday's (1978) interpersonal level of communication" (2005: 11), and further that "[r]elational work is defined as the work people invest in negotiating their relationships in interaction" (2008: 78). Relational work is not switched off and on in communication but is always involved. Locher (2004: 51) writes that "[ $\mathrm{t}]$ he process of defining relationships in interaction is called face-work or relational work", and states a preference for the term "relational work" because "it highlights the involvement of at least two interactants". The concept of face is central to relational work, though not as defined by Brown and Levinson (1987) but by Goffman (1967: 5). Face is treated as discursively constructed within situated interactions. Relational work covers "the entire continuum from polite and appropriate to impolite and inappropriate behaviour" (Locher 2004: 51; see also Locher and Watts 2005: 11). In this perspective, Brown and Levinson's work is not a theory of politeness but "a theory of facework, dealing only with the mitigation of facethreatening acts", and fails to "account for those situations in which face threat mitigation is not a priority, e.g., aggressive, abusive or rude behaviour" (Locher and Watts 2005: 10). Watts (2005b: xliii see also Locher and Watts 2005: 12; Locher 2004: 90) offers a diagram which usefully attempts to map the total spectrum of relational work, reproduced below as Figure 1.

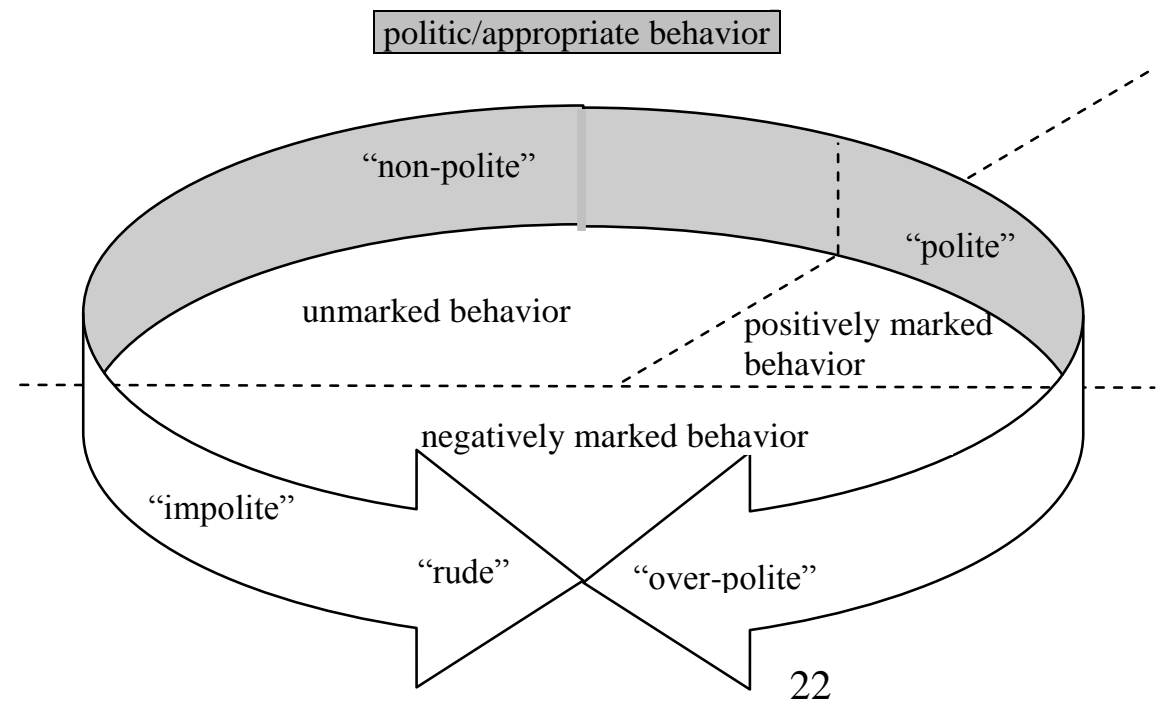


non-politic/inappropriate behavior

Figure 1. Relational work (Watts 2005b: xliii)

Relational work in this perspective incorporates the issue of whether behaviour is marked or not. Markedness here relates to appropriateness: if the behaviour is inappropriate, it will be marked and more likely to be noticed. Unmarked behaviour is what Watts $(1989,2003)$ refers to in his earlier work as "politic behaviour": "[1]inguistic behaviour which is perceived to be appropriate to the social constraints of the ongoing interaction, i.e. as non-salient, should be called politic behaviour" (Watts 2003: 19), and is illustrated by the following examples:

A: Would you like some more coffee?

B: Yes, please.

M: Hello, Mr. Smith. How are you?

S: Hello David. Fine thanks. How are you?

(Watts 2003: 186, emphasis as original)

Politeness, on the other hand, is positively marked behaviour. Watts (2003: 19) writes that "[1]inguistic behaviour perceived to go beyond what is expectable, i.e. salient behaviour, should be called polite or impolite depending on whether the behaviour itself tends towards the negative or positive end of the spectrum of politeness". By way of illustration, we can re-work Watts's examples accordingly:

A: Would you like some more coffee?

B: Yes, please, that's very kind, coffee would be wonderful.

M: Hello, Mr. Smith. It's great to see you. We missed you. How are you?

S: Hello David. I'm fine thanks. It's great to see you too. How are you?

As mentioned earlier, politic behaviour echoes Ide's (e.g. 1989, 1993) notion of "wakimae", which involves working out your position in a group and the social norms and acting accordingly. A framework that moves beyond a focus on the individual's strategic choice in redressing FTAs (cf. Brown and Levinson 1987) is in a better position to accommodate crosscultural variation. Some researchers (e.g. Meier 1995) see politeness as a matter of doing what is appropriate, but Watts is clearly right in allowing for the fact that people frequently do more than what is called for. In Watts's and Locher's view, politeness is associated with a marked surplus of relational work. One problem here, however, is that Watts's definitions, as given in the previous paragraph, suggest a hard line between politic behaviour and politeness: if it is not one, it is the other. This seems unrealistic; surely there is a scale between politic behaviour and politeness capturing degrees of difference between relatively "normal" behaviours and situations, such as greetings and leave-takings in expected contexts, and those which are more creative (see Leech 2007: 203, for a similar comment). Indeed, contrary to the definitions, the dotted lines in Figure 
1 suggest fuzziness. The other key dimension in Figure 1 is negative versus positive behaviour, presumably referring to a participant's evaluation of the behaviour. As noted in section 2.2, these labels are not in themselves sufficiently precise to capture a notion like politeness.

Spencer-Oatey's (e.g. 2000, 2002, 2005, 2007, 2008) model of "rapport management" arose from critical dissatisfaction, particularly in the cross-cultural sphere, with Brown and Levinson's model:

Taking these arguments [concerning the inadequacy of Brown and Levinson's model] into consideration, I propose a modified framework for conceptualizing face and rapport. I maintain that Brown and Levinson's (1987) conceptualization of positive face has been underspecified, and that the concerns they identify as negative face issues are not necessarily face concerns at all. I propose instead that rapport management (the management of harmony-disharmony among people) entails three main interconnected components: the management of face, the management of sociality rights and obligations, and the management of interactional goals (2008: 13)

Spencer-Oatey's rapport management framework consists of three types of face, "quality", "relational" and "social identity", ${ }^{3}$ and two types of "sociality rights". These are summarised in Table 1.

Table 1. Categories in the rapport management framework

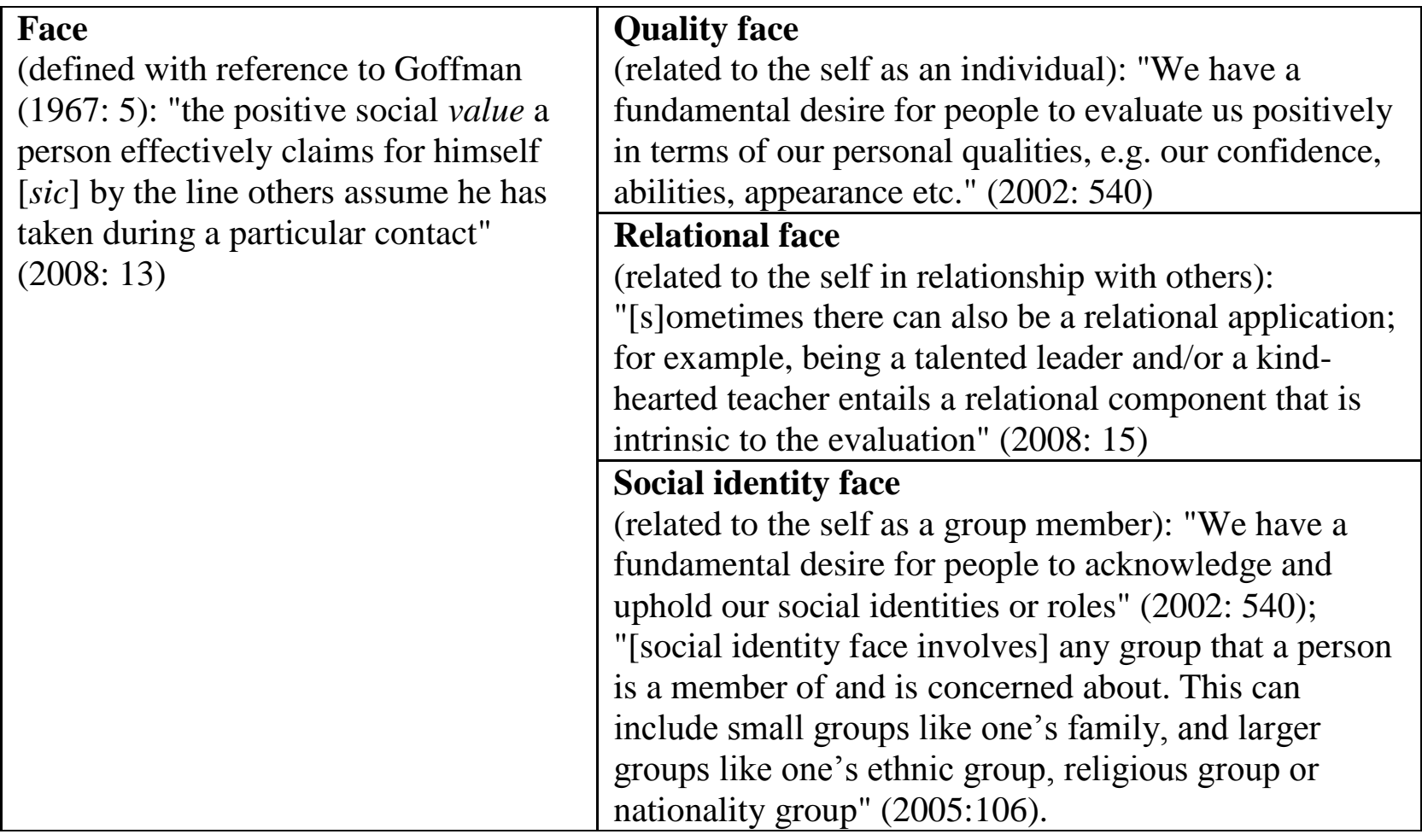


A final draft of: Culpeper, Jonathan (2011) Politeness and impoliteness. In: Karin Aijmer and Gisle Andersen (eds.)

Sociopragmatics, Volume 5 of Handbooks of Pragmatics edited by Wolfram Bublitz, Andreas H. Jucker and Klaus P. Schneider.

Berlin: Mouton de Gruyter, 391-436. This is the final draft submitted, but it may have very minor errors and infelicities.

\section{Sociality rights}

defined as the "fundamental social entitlements that a person effectively claims for him/herself in his/her interactions with others" (2008: 13)

\section{Equity rights:}

"We have a fundamental belief that we are entitled to personal consideration from others, so that we are treated fairly: that we are not unduly imposed upon, that we are not unfairly ordered about and that we are not taken advantage of or exploited" (2008: 16)

\section{Association rights:}

"We have a fundamental belief that we are entitled to social involvement with others, in keeping with the type of relationship that we have with them." (2008: 16)

Regarding interactional goals, Spencer-Oatey (2008: 17) writes:

People often (although not always) have specific goals when they interact with others. These can be relational as well as transactional (i.e. task-focused) in nature. These 'wants' can significantly affect their perceptions of rapport because any failure to achieve them can cause frustration and annoyance.

Note that Spencer-Oatey separates goals/wants from face. Spencer-Oatey (e.g. 2008) devotes considerable space elaborating how these three components - face, rights and goals - are linked to pragmatic, linguistic and contextual features. This elaboration goes well beyond simple lexically and grammatically defined output strategies or simple social variables. The important point for the model is that Spencer-Oatey provides a detailed analytical framework which we can apply to language data.

Threats to positive rapport or harmony between people can, given the three components of rapport management outlined above, be related to face, rights/obligations or interactional goals. However, rapport management is not confined, as in the case of Brown and Levinson (1987), to counterbalancing threats. Spencer-Oatey (2008:32) suggests that there are four orientations:

1. Rapport enhancement orientation: a desire to strengthen or enhance harmonious relations between the interlocutors;

2. Rapport maintenance orientation: a desire to maintain or protect harmonious relations between the interlocutors;

3. Rapport neglect orientation: a lack of concern or interest in the quality of relations between the interlocutors (perhaps because of a focus on self);

4. Rapport challenge orientation: a desire to challenge or impair harmonious relations between the interlocutors.

Rapport enhancement tallies with Leech's (1983a) accommodation of acts that simply enhance politeness, perhaps to strengthen friendship. Rapport maintenance could be simply a matter of performing politic behaviour, or a matter of restoring relations in the light of threatening behaviour. Rapport neglect accommodates Brown and Levinson's (1987) observation for the bald on record strategy that in emergency situations politeness is not an issue, along with the many other reasons why somebody may neglect relations (e.g. weighting their own concerns above that of the others). Finally, rapport challenge accommodates impoliteness, to be discussed in section 
A final draft of: Culpeper, Jonathan (2011) Politeness and impoliteness. In: Karin Aijmer and Gisle Andersen (eds.) Sociopragmatics, Volume 5 of Handbooks of Pragmatics edited by Wolfram Bublitz, Andreas H. Jucker and Klaus P. Schneider. Berlin: Mouton de Gruyter, 391-436. This is the final draft submitted, but it may have very minor errors and infelicities.

3. In the last four sentences, I have made these broad connections with some aspects of politeness. Spencer-Oatey is not at all concerned with plotting notions such as "polite" or "impolite" in her scheme; she is simply proposing a second-order framework of interpersonal relations.

\section{Frame-based}

Although, as we have already seen, some researchers have referred to the notion of a frame, it is Marina Terkourafi (e.g. 2001, 2002, 2003, 2005a, 2005b) who goes the whole hog and creates the frame-based approach to politeness, anchoring it in pragmatic theory. She argues that we should analyse the concrete linguistic realisations (i.e. formulae) and particular contexts of use which co-constitute "frames". This avoids problematic notions like directness. Moreover, "[i]t is the regular co-occurrence of particular types of context and particular linguistic expressions as the unchallenged realisations of particular acts that create the perception of politeness" (2005a: 248; see also 2005b: 213; my emphasis). The fact that the expressions are not only associated with a particular context but go unchallenged is an important point. This feature seems to be similar to Haugh's point that evidence of politeness can be found in, amongst other things, "the reciprocation of concern evident in the adjacent placement of expressions of concern relevant to the norms in both in that particular interaction" (2007b: 312). Note that the fact that we are dealing with regularities means that we can deploy quantitative as well as qualitative methodologies (a simplistic quantitative methodology, such as counting up a particular form, is not possible, as we must count up forms in particular contexts that are unchallenged). There are also some echoes of politic behaviour relating as it does to social routines. Terkourafi suggests that it is through that regularity of co-occurrence that we acquire "a knowledge of which expressions to use in which situations" (2002: 197), that is, "experientially acquired structures of anticipated 'default' behaviour" (2002: 197). She also points out that formulae are more easily processed by both speaker and hearer, when juggling face concerns, goals, and so on, and also that using them demonstrates a knowledge of community norms (2002: 196). Thus, "formulaic speech carries the burden of polite discourse" (2002: 197; see also references given in 2005b: 213). The fact that this is so accounts for the observation that politeness often passes unnoticed (Kasper 1990: 193).

Of course, it is not the case that such conventionalised formulae - the stuff of anticipated politeness - constitute the only way politeness is conveyed and understood. Terkourafi (e.g. 2001, 2005b) develops Neo-Gricean pragmatics (e.g. Levinson, 2000) to account for more implicational/inferential modes. The background to this lies in Grice's (1975) distinction between particularised and generalised implicatures, and its elaboration by Levinson (e.g. 1995, 2000). Particularised implicatures are worked out from scratch on the basis of the particular context the utterance appears in; generalised implicatures have a more stable association with particular linguistic forms (cf. Grice 1989: 37 (this is a reprint of his 1975 paper)). Levinson's particular contribution was to characterise generalised implicatures as a level of meaning between particularised implicatures and fully conventionalised (non-defeasible) implicatures. Terkourafi's further contribution was to split generalised implicatures into two, a division based on the relationship with context. The first captures situations where the implicature is weakly contextdependent, requiring a minimal amount of contextual information relating to the social context of use in which the utterance was routinised and thus conventionalised to some degree; the second, as described by Levinson, captures situations where the implicature is even more weakly 
A final draft of: Culpeper, Jonathan (2011) Politeness and impoliteness. In: Karin Aijmer and Gisle Andersen (eds.)

Sociopragmatics, Volume 5 of Handbooks of Pragmatics edited by Wolfram Bublitz, Andreas H. Jucker and Klaus P. Schneider.

Berlin: Mouton de Gruyter, 391-436. This is the final draft submitted, but it may have very minor errors and infelicities.

context-dependent - its meaning is presumed in a variety of contexts. The resulting implicational/inferential cline is as follows (Terkourafi 2005b: 211-2):

$\begin{array}{llll}\begin{array}{l}\text { Particularised } \\ \text { implicature } \\ \text { (utterance- }\end{array} & \begin{array}{l}\text { Generalised } \\ \text { implicature I } \\ \text { token meaning }\end{array} & \begin{array}{l}\text { Generalised } \\ \text { implicature II } \\ \text { (utterance-type }\end{array} & \begin{array}{l}\text { Coded } \\ \text { meaning } \\ \text { (sentence } \\ \text { merived in }\end{array} \\ \text { nonce context) } & \text { presumed in } & \text { meaning } & \text { presumed in all } \\ & \text { minimal } & \text { contexts ceteris } \\ \text { context) } & \text { paribus) }\end{array}$

Hitherto, standard, classical Gricean accounts of politeness (e.g. Leech 1983a) have made no explicit connection with generalised implicatures, instead discussing politeness in terms of the recovery of the speaker's intentions in deviating from Gricean cooperativeness on a particular occasion (i.e. in terms of particularised implicatures) (see section 2.3.1). In the introduction to their second edition, Brown and Levinson (1987: 6-7) admit that they may have underplayed the role of generalised conversational implicatures. Terkourafi, in contrast, argues that, whilst politeness can involve full inferencing in a nonce context, what lies at its heart is a generalised implicature of the first type given above. Her argument is neatly summarised here (Terkourafi 2005a: 251, original emphasis):

Politeness is achieved on the basis of a generalised implicature when an expression $x$ is uttered in a context with which - based on the addressee's previous experience of similar contexts - expression $x$ regularly cooccurs. In this case, rather than engaging in full-blown inferencing about the speaker's intention, the addressee draws on that previous experience (represented holistically as a frame) to derive the proposition that "in offering expression $x$ the speaker is being polite" as a generalised implicature of the speaker's utterance. On the basis of this generalised implicature, the addressee may then come to hold the further belief that the speaker is polite.

Terkourafi offers a coherent, rich, pragmatic account of politeness. In a number of her publications she investigates politeness in Cypriot Greek. It remains for future research to apply the frame-based approach to other contexts.

\section{Impoliteness}

Although the study of impoliteness has a fairly long history (usually in the guise of the study of swearing, an example being Montagu 2001 [1968]) and although early scientific attempts to address the topic (e.g. Lachenicht's 1980) did not galvanise scholars, momentum has been increasing, with the arrival of, for example, Lakoff (1989), Austin (1990), Beebe (1995), Culpeper 1996, Kienpointner (1997), Tracy and Tracy (1998), Culpeper et al. (2003), Mills (2003) and Culpeper (2005). The year 2008 has been an especially important year, as the field saw the arrival of its first monograph, Bousfield (2008), its first volume of papers, Bousfield and Locher (2008), and first journal special issue devoted to impoliteness: "Impoliteness: Eclecticism and Diaspora" (Journal of Politeness Research 4 (2), edited by Bousfield and Culpeper). ${ }^{4}$

Towards the end of his book, Eelen (2001: 245-6) supplies a summary list of problems with traditional politeness models, problems which are a "good starting point for the research for a more adequate model of politeness" (2001: 245). The first listed is: "The inability to adequately account for impoliteness by the same concepts that explain politeness" (2001:245). This is important, because readers will have noted in the course of this chapter various places where 
A final draft of: Culpeper, Jonathan (2011) Politeness and impoliteness. In: Karin Aijmer and Gisle Andersen (eds.) Sociopragmatics, Volume 5 of Handbooks of Pragmatics edited by Wolfram Bublitz, Andreas H. Jucker and Klaus P. Schneider. Berlin: Mouton de Gruyter, 391-436. This is the final draft submitted, but it may have very minor errors and infelicities.

politeness models accommodate or at least having a bearing on impoliteness. Earlier in his book Eelen (2001:98-104) elaborates on the specific problems, which are:

- treating impoliteness as failed or absent politeness (e.g. the failure to redress or redress adequately a FTA);

- treating, explicitly or otherwise, impoliteness as the opposite of politeness, yet only developing concepts for explaining politeness (e.g. Blum-Kulka [1992] 2005 develops cultural scripts to explain politeness but not impoliteness).

Of course, it should be stressed that these problems, especially the first one, do not apply equally to all politeness models (it does not apply, for example, to Leech 1983a). What is generally true is that we do not have a complete apparatus for accommodating or explaining the rich array of communicative action undertaken to achieve and/or perceived by participants as achieving impoliteness (see, for example, the descriptions in Lachenicht 1980; Beebe 1995; Culpeper 1996; Bousfield 2008).

At this point we should pause to reflect on whether Eelen is correct. Should a model of politeness account for impoliteness using the same concepts, or is a completely different model required? Recollect that both of the relational frameworks discussed in the previous section accommodate, explicitly or implicitly, both politeness and impoliteness. But the important distinction is that relational frameworks are not models of politeness themselves; they are models of interpersonal relations which may accommodate at least some aspects of politeness, impoliteness, and so on. Still, it cannot be denied that impoliteness phenomena are intimately connected with politeness. One way in which the degree of impoliteness varies is according to the degree of politeness expected: if I told the Vice Chancellor of my University to be quiet, I suspect considerably more offence would be taken than if I told my young daughter to do the same. Moreover, the fact that sarcasm trades off politeness is further evidence of this relationship. For example, "thank you" (with exaggerated prosody) uttered by somebody to whom a great disfavour has been done, reminds hearers of the distance between favours that normally receive polite thanks and the disfavour in this instance. There are, however, also some important differences between politeness and impoliteness. Within a relational approach, impoliteness can be associated with a negative evaluation as opposed to a positive evaluation, which can be aligned with politeness. However, as I have pointed out on a number of occasions, the categories positive and negative are very broad. When we look at the specifics, the polite/impolite opposition runs into some difficulties.

One possible characteristic of politeness, as noted above, is consideration. In a very broad sense any impoliteness involves being inconsiderate, but defining something in terms of a negative (i.e. what it is not) is not very informative about what it actually is. I conducted a study of 100 impoliteness events reported by British undergraduates. 133 of the total of 200 descriptive labels that informants supplied for those events fell into 6 groups (in order of predominance): patronising, inconsiderate, rude, aggressive, inappropriate and hurtful (see Culpeper forthcoming). Clearly, being inconsiderate is a descriptive label that strikes a chord with participants. However, patronising, by far the most frequent label, does not have a ready opposite concept in politeness theory. Presumably, it relates to an abuse of power, a lack of deference, but neither power nor deference are well described in the classic politeness theories. Similarly, aggressive, with overtones of violence and power, has only a very general opposite in politeness theory, that of harmony. And there are yet other differences or cases where there do 
not appear to be easy diametric opposites between impoliteness and politeness. Anger is one of the most frequent emotional reactions associated with impoliteness, particularly when a social norm or right is perceived to have been infringed (Culpeper forthcoming). But anger lacks a similarly specific emotional opposite associated with politeness. Furthermore, taboo lexical items appear relatively frequently in impolite language. Lexical euphemisms, however, whilst they are associated with politeness, play a minor role. ${ }^{5}$

One way in which there is an obvious difference between politeness and impoliteness is that impoliteness has its own set of conventionalised impolite formulae. I understand conventionalisation here in the same way as Terkourafi (e.g. 2003), namely, items conventionalised for a particular context of use. As we saw in section 2.3.2, for such items to count as polite they must go unchallenged (e.g. Terkourafi 2005a; see also Haugh 2007b, for a related point). Conversely, then, a characteristic of conventionally impolite formulae is that they are challenged. In my data, by far the most frequent impolite formulae type are insults. These fall into the following four groups (all examples are taken from naturally-occurring data; square brackets give an indication of structural slots, which are optional to varying degrees, and slashes separate attested examples within ):

1. Personalized negative vocatives

- [you] [fucking/rotten/dirty/fat/little/etc.][moron/fuck/plonker/dickhead/ berk/pig/shit/bastard/loser/liar/minx/brat/slut/squirt/sod/bugger/etc.] [you]

2. Personalized negative assertions

- $\quad$ [you] [are] [so/such a] [shit/stink/thick/stupid/bitchy/bitch/hypocrite/ disappointment/gay/nuts/nuttier than a fruit cake/hopeless/pathetic/fussy/ terrible/fat/ugly/etc.]

- $\quad$ [you] [can't do] [anything right/basic arithmetic/etc.]

- $\quad$ [you] [disgust me/make me] [sick/etc.]

3. Personalized negative references

- $\quad$ [your] [stinking/little] [mouth/act/arse/body/corpse/hands/guts/trap/breath/etc.]

4. Personalized third-person negative references (in the hearing of the target)

- $\quad$ [the] [daft] [bimbo]

- $\quad$ [she] ['s] [nutzo]

Other impolite formulae types that emerged are: Pointed criticisms/complaints, Challenging or unpalatable questions and/or presuppositions, Condescensions, Message enforcers, Dismissals, Silencers, Threats, Curses and ill-wishes, and Non-supportive intrusions (further detail and exemplification can be found in Culpeper forthcoming).

Of course, whether or not impoliteness formulae result in impoliteness will depend on the hearer's assessment of its usage in context. Consider this example:

[Lawrence Dallaglio, former England Rugby captain, describing the very close family in which he grew up]

As Francesca and John left the house, she came back to give Mum a kiss and they said goodbye in the way they often did. 'Bye, you bitch,' Francesca said. 'Get out of here, go on, you bitch,' replied Mum.

It's in the blood: My life (2007), from an extract given in The Week, 10/11/07 
A final draft of: Culpeper, Jonathan (2011) Politeness and impoliteness. In: Karin Aijmer and Gisle Andersen (eds.)

Sociopragmatics, Volume 5 of Handbooks of Pragmatics edited by Wolfram Bublitz, Andreas H. Jucker and Klaus P. Schneider. Berlin: Mouton de Gruyter, 391-436. This is the final draft submitted, but it may have very minor errors and infelicities.

Here, in the direct speech, we see a conventionalised insulting vocative, "you bitch", and also a conventionalised dismissal, "get out of here". McEnery (2006: 39, 236) provides corpus evidence that there is a strong tendency in British English for bitch to be used between women, as here. Nevertheless, these items project contexts that are dramatically at odds with the situation within which they are uttered. Rather than antagonistic relationships, hate, coercion, and so on, we have a strong loving family unit (Francesca has just demonstrated her affection by giving her mother a kiss). The recontextualisation of impoliteness formulae in socially opposite contexts reinforces socially opposite effects, namely, affectionate, intimate bonds amongst individuals and the identity of that group. Here we have the opposite of genuine impoliteness, that is, mock impoliteness, which consists of impolite forms whose effects are (at least theoretically for the most part) cancelled by the context (the term "mock impoliteness" is used in Leech 1983a; also see Bernal 2008, for a discussion of genuine vs. non-genuine impoliteness). Banter is the key everyday label, though most types of teasing and some jokes also have in common the fact that they involve mock impoliteness. One of the lacunae in Brown and Levinson (1987) is that they do not treat banter at all; in contrast, Leech (1983a) describes mock impoliteness within his Banter Principle:

In order to show solidarity with h, say something which is (i) obviously untrue, and (ii) obviously impolite to $\mathrm{h}$ " [and this will give rise to an interpretation such that] "what s says is impolite to h and is clearly untrue. Therefore what s really means is polite to $\mathrm{h}$ and true. (1983a: 144)

Banter, of course, also exists in a heavily ritualised form as a kind of language game - a specific activity type. In America some forms of this activity are known as "sounding", "playing the dozens" or "signifying", which takes place particularly amongst black adolescents (Abrahams 1962; Labov's 1972; for a recent and particularly nuanced account of banter in a community in France, see Tetreault 2009)

Needless to say, impoliteness is frequently achieved and understood without the use of formulae, in other words, through implicit means, as illustrated in the following example (a diary report from a British undergraduate):

As I walked over to the table to collect the glasses, Sarah's said to Joe 'come on Joe lets go outside', implying she didn't want me there. This was at the pub on Sunday night, and I just let the glasses go and walked away.

I didn't particularly feel bad, but angry at the way she had said that straight away when I got there. We aren't particularly friends but she was really rude in front of others.

The interpretation of Sarah's utterance partly rests on assumptions about for whom the message is intended. Clearly, the informant assumes that, whilst the addressee is Joe, the target is her, something which seems to be supported by the fact that it was said "straight away when I got there". It is possible, of course, that the offender also used non-verbal means to clarify the target, such as looking at her whilst she spoke. Taking the informant as the target, the utterance "come on Joe lets go outside" seems to have no relevance at all for her: it flouts the Maxim of relation (Grice 1975). The informant draws the implicature that going outside entails moving away from where she is, in other words, she is being excluded. In my data, the most frequent implicit strategy by which impoliteness is understood is sarcasm. Sarcasm can be understood as mock politeness, that is, the politeness is not understood to be genuine (cf. Culpeper 1996, who draws on Leech 1983a). The message conveyed is partially mixed: some aspects, such as the use of 
A final draft of: Culpeper, Jonathan (2011) Politeness and impoliteness. In: Karin Aijmer and Gisle Andersen (eds.)

Sociopragmatics, Volume 5 of Handbooks of Pragmatics edited by Wolfram Bublitz, Andreas H. Jucker and Klaus P. Schneider.

Berlin: Mouton de Gruyter, 391-436. This is the final draft submitted, but it may have very minor errors and infelicities.

politeness formulae, suggest politeness; other aspects, typically contextual or co-textual, suggest impoliteness. For example, a member of staff at Lancaster University writing to complain about somebody backing into her car in the car park and then disappearing concludes her complaint: "Thank you SO VERY MUCH". Note the capitalisation here. The parallel in spoken language is the prosody. Mixed sarcastic messages often involve multimodality: the verbal content conflicting with the prosody or visual aspects. In all such cases, the overall assessment must be weighted towards aspects suggesting impoliteness, leaving the aspects suggesting politeness (typically the formulaically polite words) as a superficial veneer, reminding the target of the distance between the polite context and the impolite one in hand.

To some extent, the jury is still out on whether a theory of politeness should encompass impoliteness and also how it should do so. One of the problems in moving this issue forward is that there are so many different politeness models.

\section{Concluding remarks on the definition of politeness}

Although the discussion thus far has presented various definitions of politeness which at least capture some aspects of what it is and has conveyed a sense of what politeness involves, it does not quite fully pin down what it is. I propose a definition of politeness that might be said to be an attitudinal view:

Politeness involves (a) an attitude comprised of particular positive evaluative beliefs about particular behaviours in particular social contexts, (b) the activation of that attitude by those particular in-context-behaviours, and (c) the actual or potential description of those in-context-behaviours and/or the person who produced them as polite, courteous, considerate, etc.. Linguistic politeness refers to linguistic or behavioural material that is used to trigger politeness attitudes. Politeness strategies (plans of action for achieving politeness effects) and formulae (linguistic/behavioural forms for achieving politeness effects) are conventionally associated to some degree with contexts in which politeness attitudes are activated. Impoliteness, although its performance involves significant differences, can be defined along similar but contrary lines: it involves negative attitudes activated by in-context-behaviours which are associated, along with the person who gave rise to them, with impoliteness metalanguage (e.g. impolite, rude, discourteous, etc.).

Like Haugh (2007a: 91), I see politeness as an interpersonal attitude. Attitudes, of course, are well-established in social psychology, and especially language attitude research. An attitude involves a favourable or unfavourable reaction to stimuli, and has cognitive, affective and behavioural elements (see Bradac et al. 2001, and references therein). Note that conceiving of politeness as an attitude accommodates the frequently stated point that politeness is subjective and evaluative (e.g. Eelen 2001; Watts 2003; Spencer-Oatey 2005; Ruhi 2008). However, it should be noted that simply referring to "positive" evaluative beliefs is not sufficiently specific. It is unlikely that politeness involves any positive belief. For example, amusing somebody is an interpersonal activity that is generally viewed positively, but it is not at all clear that it would normally be considered a matter of politeness. A key objective for researchers is to understand the subset of positive evaluative beliefs that count as politeness on a particular occasion. The concept of face (Goffman 1967) is one mechanism for trying to doing this. However, I am not convinced that face easily accommodates all politeness-relevant positive beliefs. People also 
A final draft of: Culpeper, Jonathan (2011) Politeness and impoliteness. In: Karin Aijmer and Gisle Andersen (eds.)

Sociopragmatics, Volume 5 of Handbooks of Pragmatics edited by Wolfram Bublitz, Andreas H. Jucker and Klaus P. Schneider.

Berlin: Mouton de Gruyter, 391-436. This is the final draft submitted, but it may have very minor errors and infelicities.

have such beliefs about social organisation and behaviours within social organisations, about how people should be treated, about what is fair and what is not, and some of these beliefs are associated with politeness. Such beliefs -- which can include beliefs about facework itself -- are part of a society's moral order. For example, it was very clear from my diary report data that friends and lovers have clear expectations about behaviours in that role (including, for example, a particular amount of attention paid to each other). Spencer-Oatey's (e.g. 2008) rapport management framework does a good job of accommodating this array of evaluative beliefs, incorporating as it does the notion of sociality rights. Still, even with Spencer-Oatey's more sophisticated framework there is no guarantee that every positive evaluative belief necessarily correlates with politeness attitudes. The way I have tried to remedy this in my definition is not only to link politeness attitudes to the behaviours that trigger them but also to the actual or potential post-facto metalinguistic description of those behaviours and/or the person who produced them as polite (or a closely related synonym).

Linguistic politeness refers to linguistic or behavioural forms that are (conventionally) associated with contexts in which politeness attitudes are activated (this view is consistent with, for example, Terkourafi e.g. 2001, outlined above). We acquire linguistic politeness from our experience of social interactions (e.g. Ervin-Tripp et al. 1990; Escandell-Vidal 1996; Snow et al. 1990). It involves the use of expressions that are both contextually appropriate and positively evaluated by the target (cf. Locher and Watts 2005). Remember the use of please, as discussed towards the beginning of this chapter. It is not used by anybody to anybody, or in any context, and when it is used, it is generally considered interpersonally positive. The point about politeness routines/markers is that knowledge of both their appropriate context and their positive social meaning has become conventionally associated with the form. Of course, this does not mean that simply using a politeness routine/marker will result in politeness being achieved. Politeness always involves an overall contextual judgment; as is frequently pointed out, politeness is not solely determined by forms alone (cf. Fraser and Nolan, 1981: 96; Watts, 2003: 168; Locher and Watts, 2008: 78). Thus, 'Go to hell please', said to get rid of somebody, might well be considered interpersonally negative, despite the fact that a conventional politeness marker has been used. In fact, this particular utterance achieves its power, because politeness is part of the conventionalised meaning of please.

\section{References}

Abrahams, Roger D.

1962 Playing the dozens. Journal of American Folklore 75: 209-220.

Aijmer, Karin

1996 Conversational Routines in English: Convention and Creativity. London and New York: Longman.

Arndt, Horst and Richard Wayne Janney

1987 Intergrammar: Toward an Integrative Model of Verbal, Prosodic and Kinesic Choices in Speech. Berlin: De Gruyter.

Arundale, Robert B.

1999 An alternative model and ideology of communication for an alternative to politeness theory. Pragmatics 9 (1): 119-153.

2006 Face as relational and interactional: a communication framework for research on face, facework, and politeness. Journal of Politeness Research: Language, Behaviour, 
Austin, John L.

Culture 2 (2): 193-217.

1962 How to Do Things with Words. Oxford: Oxford University Press.

Austin, Paddy

1990 Politeness revisited - the dark side. In: Bell, Allen and Janet Holmes (eds)., New Zealand ways of speaking English. Multilingual Matters 65. Philadelphia: Multilingual Matters.

Bargiela-Chiappini, Francesca

2003 Face and politeness: New (insights) for old (concepts) Journal of Pragmatics 35 (1011): 1453-1469.

Baxter, Leslie A.

1984 'An investigation of compliance-gaining as politeness', Human Communication Research, 10, 3, 427-456

Beebe, Leslie, M.

1995 'Polite fictions: Instrumental rudeness as pragmatic competence. Linguistics and the Education of Language Teachers: Ethnolinguistic, Psycholinguistics and Sociolinguistic Aspects'. Georgetown University Round Table on Languages and Linguistics. Georgetown: Georgetown University Press.

Bernal, Maria

2008 Do insults always insult? Genuine politeness versus non-genuine politeness in colloquial Spanish [¿Insultan los insultos? Descortesía auténtica vs. descortesía no auténtica en el español coloquial]. Pragmatics 18 (4): 775-802.

Biber, Douglas, Stig Johansson, Geoffrey Leech, Susan Conrad and Edward Finegan 1999 Longman Grammar of Spoken and Written English. Harlow: Pearson Education Blum-Kulka, Shoshana

1985 The Language of requesting in Israeli Society. In: Forgas, Joseph (ed.) Language and Social Situations, New York: Springer-Verlag, 113-39

1987 Indirectness and politeness in requests: Same or different?' Journal of Pragmatics, 11: $131-146$

2005 [1992] The metapragmatics of politeness in Israeli society. In: Watts, Richard J., Sachiko Ide and Konrad Ehlich (eds.) Politeness in Language: Studies in its History, Theory and Practice. Berlin and New York: Mouton de Gruyter, 255-280.

Bourdieu, Pierre

1991 Language and Symbolic Power. Cambridge: Polity Press.

Bousfield, Derek

2008 Impoliteness in Interaction. Philadelphia and Amsterdam: John Benjamins.

Bousfield, Derek and Jonathan Culpeper (eds)

Impoliteness: Eclecticism and Diaspora. Special issue of the Journal of Politeness

Research 4 (2).

Bousfield, Derek and Miriam Locher (eds)

2008 Impoliteness in Language: Studies on its Interplay with Power in Theory and Practice. Berlin and New York: Mouton de Gruyter.

Bradac, James, J. Cargile, Aaron Castelan and Jennifer S. Hallett

2001 Language Attitudes: Retrospect, Conspect, and Prospect. In: W. Peter Robinson and Howard Giles (eds) The New Handbook of Language and Social Psychology. Chichester: John Wiley, 137-55. 
Bravo, Diana (ed.)

2008 (Im)politeness in Spanish-speaking socio-cultural contexts. Special issue of Pragmatics 18 (4).

Brookins, Timothy

2010 A politeness analysis of Catullus' polymetric poems: Can Leech's GSP cross the Ancient-Modern divide. Journal of Pragmatics 42: 1283-1295.

Brown, Bert R.

1970 'Face-saving following experimentally induced embarrassment', Journal of Experimental Social Psychology, 6, 255-271

Brown, Penelope

1995 Politeness strategies and the attribution of intentions: The case of Tzeltal irony. In: Esther Goody (ed.) Social intelligence and interaction: Expressions and Implications of the Social Bias in Human Intelligence. Cambridge: Cambridge University Press, 153-174.

Brown, Roger and Albert Gilman

1989 'Politeness theory and Shakespeare's four major tragedies', Language in Society, 18, $159-212$

Brown, Penelope and Stephen C. Levinson

1987 [1978] Politeness. Some universals in language usage. Cambridge University Press:

Christie, Chris Cambridge.

2007 Relevance theory and politeness. Journal of Politeness Research: Language, Behaviour, Culture 3: 269-294.

Cody, Michael, Margaret McLaughlin and Michael J. Schneider

1981 'The impact of relational consequences and intimacy on the selection of interpersonal persuasion tactics: A reanalysis', Communication Quarterly, 29, 91-106

Coupland, Nikolas, Karen Grainger and Justine Coupland

1988 'Politeness in context: Intergenerational issues (Review article)', Language in Society, 17, 253-262

Craig, Robert T., Karen Tracy and Frances Spisak

1986 'The discourse of requests: Assessment of a politeness approach', Human Communication Research, 12, 4, 437-468

Culpeper, Jonathan

1996 'Towards an anatomy of impoliteness', Journal of Pragmatics, 25, 349-67.

2005 'Impoliteness and entertainment in the television quiz show: The Weakest Link', Journal of Politeness Research 1: 35-72.

2011 Impoliteness: Using Language to Cause Offence. Cambridge: Cambridge University Press.

Culpeper, Jonathan, Derek Bousfield and Anne Wichmann

2003 'Impoliteness reviewed: With special reference to dynamic and prosodic aspects', Journal of Pragmatics 35: 1545-1579.

Domenici, Kathy and Stephen W. Littlejohn

2006 Facework. London: Sage.

Duranti, Alessandro and Charles Goodwin (eds)

1992 Rethinking Context: Language as an Interactive Phenomenon. Cambridge: Cambridge University Press. 
Edwards, Derek and Jonathan Potter

1992 Discursive Psychology. London: Sage.

Eelen, Gino

2001 A Critique of Politeness Theories. Manchester: St. Jerome.

Ervin-Tripp, Susan M., Nancy Bell, Martin Lampert and Amy Strage

1987 Understanding requests. Linguistics 25 (1): 107-143.

Ervin-Tripp, Susan M., Jiansheng Guo and Martin Lampert

1990 Politeness and persuasion in children's control acts. Journal of Pragmatics 14: 307331.

Escandell-Vidal, Victoria

1996 Towards a cognitive approach to politeness. In: Katarzyna Jaszczolt and Ken Turner (eds) Contrastive Semantics and Pragmatics, Vol. 2: Discourse Strategies. Oxford: Pergamon, pp. 621-650.

1998 Intonation and Procedural Encoding: The Case of Spanish Interrogatives. In: Villy Rouchota and Andreas H. Jucker (eds) Current Issues in Relevance Theory. Amsterdam: John Benjamins, pp. 169-203.

Fairclough, Norman 1989 Language and Power. ( $1^{\text {st }}$ ed) London: Longman.

Falbo, Toni and Letitia A. Peplau

1980 'Power strategies in intimate relationships', Journal of Personality and Social Psychology, 38, 4, 618-628.

Field, Margaret

1998 Politeness and indirection in Navajo directives. Southwest Journal of Linguistics 17(2): 23-34.

Fraser, Bruce

1990 'Perspectives on politeness', Journal of Pragmatics, 14(2): 219-36.

1999 Wither politeness? Plenary lecture delivered at the International Symposium for

Linguistic Politeness, Bangkok, 8 December 1999.

Fraser, Bruce and William Nolan

1981 The association of deference with linguistic form. International Journal of the Sociology of Language 27: 93-109.

Geis, Michael

1995 Speech Acts and Conversational Action. Cambridge: Cambridge University Press.

Gibbs, Raymond W.

1981 Your wish is my command: Convention and context in interpreting indirect requests.

Journal of Verbal Learning and Verbal Behavior 20: 431-444.

Goffman, Erving

1967 Interaction ritual. Chicago: Aldine Publishing.

Grice, H. Paul

1957 Meaning. The Philosophical Review 66: 377-88.

1969 Utterer's Meaning and Intentions. The Philosophical Review 68: 147-77.

1975 Logic and conversation. In: Peter Cole and Jerry Morgan (eds) Syntax and Semantics

3: Speech Acts. London and New York: Academic Press, pp. 41-58.

1989 Studies in the Way of Words. Cambridge, Massachusetts: Harvard University Press.

$\mathrm{Gu}$, Yueguo

1990 Politeness phenomena in modern Chinese. Journal of Pragmatics 14 (2): 237-257. 
A final draft of: Culpeper, Jonathan (2011) Politeness and impoliteness. In: Karin Aijmer and Gisle Andersen (eds.)

Sociopragmatics, Volume 5 of Handbooks of Pragmatics edited by Wolfram Bublitz, Andreas H. Jucker and Klaus P. Schneider.

Berlin: Mouton de Gruyter, 391-436. This is the final draft submitted, but it may have very minor errors and infelicities.

Halliday, Michael A. K.

1978 Language as Social Semiotic: The Social Interpretation of Language and Meaning. London: Edward Arnold.

Harris, Sandra

2001 Being politically impolite: Extending politeness theory to adversarial political discourse. Discourse and Society 12 (4): 451-472.

2003 Politeness and power: Making and responding to requests in institutional settings. Text - Interdisciplinary Journal for the Study of Discourse. 23(1): 27-52.

Haugh, Michael

2003 Anticipated versus inferred politeness. Multilingua 22 (4): 397-413.

2007a The co-constitution of politeness implicature in conversation. Journal of Pragmatics 39 (1): 84-110.

2007b The discursive challenge to politeness research: An international alternative. Journal of Politeness Research 3(7): 295-317.

2008 Intention in pragmatics. Intercultural Pragmatics 5 (2): 99-110.

Ho, David Yau-fai

1976 On the concept of face. American Journal of Sociology 81: 867-84.

Holmes, Janet

2005 Politeness and postmodernism - an appropriate approach to the analysis of language and gender? Journal of Sociolinguistics 9 (1): 108-117.

Holmes, Janet and Maria Stubbe

2003 Power and Politeness in the Workplace: A Sociolinguistic Analysis of Talk at Work. Pearson, Education, Edinburgh.

Holmes, Janet and Stephanie Schnurr

2005 Politeness, humor and gender in the workplace: Negotiating norms and identifying contestation. Journal of Politeness Research: Language, Behaviour, Culture 1 (1): 121-149.

Holtgraves, Thomas

1986 'Language structure in social interaction: Perceptions of direct and indirect speech acts and interactants who use them', Journal of Personality and Social Psychology, 51, 2, 305-314.

1994 Communication in context: The effects of speaker status on the comprehension of indirect requests. Journal of Experimental Psychology: Learning, Memory and Cognition 20: 1205-1218.

Holtgraves, Thomas and Joong-Nam Yang

1990 'Politeness as universal: Cross-cultural perceptions of request strategies and inferences based on their use', Journal of Personality and Social Psychology, 59 (4): 719-29

1992 The interpersonal underpinnings of request strategies: General principles and individual differences. Journal of Personality and social Psychology 62 (2): 246-256.

$\mathrm{Hu}$, Hsien Chin

1944 The Chinese concepts of "face". American Anthropologist 46: 45-64.

Ide, Sachiko

1989 Formal forms and discernment. Two neglected aspects of universals of linguistic politeness. Multilingua 8(2-3): 223-248. 
A final draft of: Culpeper, Jonathan (2011) Politeness and impoliteness. In: Karin Aijmer and Gisle Andersen (eds.)

Sociopragmatics, Volume 5 of Handbooks of Pragmatics edited by Wolfram Bublitz, Andreas H. Jucker and Klaus P. Schneider.

Berlin: Mouton de Gruyter, 391-436. This is the final draft submitted, but it may have very minor errors and infelicities.

1993 Preface: The search for integrated universals of linguistic politeness. Multilingua 12 (1): 7-11.

Jary, Mark

1998 Relevance theory and the communication of politeness. Journal of Pragmatics 30: 119.

Kasper, Gabriele

1990 Linguistic politeness: current research issues. Journal of Pragmatics 14 (2): 193-218.

Kienpointner, Manfred

1997 Varieties of rudeness: Types and functions of impolite utterances. Functions of

Language 4 (2): 251-287.

Labov, William

1972 Language in the Inner City: Studies in the Black English Vernacular. Oxford:

Blackwell.

Lachenicht, Lance G.

1980 Aggravating language: a study of abusive and insulting language. International Journal of Human Communication 13 (4): 607-688.

Lakoff, Robin T.

1973 The logic of politeness; or, minding your p's and q's'. Papers from the Ninth

Regional Meeting of the Chicago Linguistic Society: 292-305.

1989 The limits of politeness: Therapeutic and courtroom discourse. Multilingua 8 (2-3): 101-129.

Leech, Geoffrey N.

1977 Language and Tact. Linguistic Agency University of Trier, Series A, Paper No.46.

[Reprinted in Leech, G. (1980) Explorations in semantics and pragmatics.

Pragmatics and Beyond I(5). Amsterdam: John Benjamins, 79-117.]

1983a Principles of Pragmatics. London: Longman.

1983b Pragmatics, discourse analysis, stylistics and "the celebrated letter". Prose Studies 6(2): 141-57.

1992 Pragmatic principles in Shaw's You Never Can Tell. In: Toolan, Michael (ed.) Language, Text and Context, London: Routledge, 259-278.

2003 Towards an anatomy of politeness in communication. International Journal of Pragmatics 14: 101-123.

2007 Politeness: Is there an East-West divide? Journal of Politeness Research: Language, Behaviour, Culture 3 (2): 167-206.

2009 How far can a theory of politeness be a theory of impoliteness? Illustrated from

Edward Albee's Who's Afraid of Virginia Woolf. Plenary lecture delivered at the Linguistic Impoliteness and Rudeness Conference: LIAR II, Lancaster, 30 June 2009.

Leichty, Greg, and James Applegate

1991 Social cognitive and situational influences on the use of face-saving persuasive strategies. Human Communication Research 17: 451-484.

Levinson, Stephen C.

1995 Interactional biases in human thinking. In: Esther N. Goody (ed.) Social Intelligence and Interaction: Expressions and Implications of the Social Bias in Human Intelligence. Cambridge: Cambridge University Press, pp. 221-260.

2000 Presumptive Meanings: The Theory of Generalised Conversational Implicature. 
Cambridge, Massachusetts: M.I.T. Press.

Lim, Tae-Seop and John W. Bowers

1991 'Face-work: Solidarity, approbation, and tact', Human Communication Research, 17, 415-50.

Locher, Miriam A.

2004 Power and Politeness in Action: Disagreements in Oral Communication. Berlin and New York: Mouton de Gruyter.

2006 Polite behaviour within relational work. The discursive approach to politeness. Multilingua 25 (3): 249-267.

Locher, Miriam A. and Derek Bousfield

2008 Introduction: Impoliteness and power in language. In: Derek Bousfield and Miriam A. Locher (eds) Impoliteness in Language: Studies on its Interplay with Power in Theory and Practice. Berlin and New York: Mouton de Gruyter, pp. 1-13.

Locher, Miriam A. and Richard J. Watts

2005 Politeness theory and relational work. Journal of Politeness Research: Language, Behaviour, Culture 1 (1): 9-33.

2008 Relational work and impoliteness: Negotiating norms of linguistic behaviour. In: Derek Bousfield and Miriam A. Locher (eds) Impoliteness in Language: Studies on its Interplay with Power in Theory and Practice. Berlin and New York: Mouton de Gruyter, pp. 77-99.

Lustig, Myron W. and Stephen King

1980 'The effect of communication apprehension and situation on communication strategy choices', Human Communication Research, 7, 74-82.

Mao, LuMing Robert

1994 Beyond politeness theory: 'Face' revisited and renewed. Journal of Pragmatics 21 (5): 451-486.

Matsumoto, Yoshiko

1988 Reexamination of the universality of face: politeness phenomena in Japanese. Journal of Pragmatics 12 (4): 403-426.

McEnery, Anthony M.

2006 Swearing in English: Bad Language, Purity and Power from 1586 to the Present.

London: Routledge.

Meier, Ardith J.

1995 Defining politeness: universality in appropriateness. Language Sciences, 17 (4): 345 356.

Mills, Sara

2003 Gender and Politeness. Cambridge: Cambridge University Press.

Montagu, Ashley

2001 [1967] Anatomy of Swearing. Pennsylvania: University of Pennsylvania Press.

Mullany, Louise

2004 Gender, politeness and institutional power roles: Humour as a tactic to gain compliance in workplace business meetings. Multilingua 23(1-2): 13-37.

Myers, Greg

1991 Politeness and certainty: The language of collaboration in an AI project, Social Studies of Science, 21 (1): 37-73.

Nwoye, Onuigbo G. 
1992 Linguistic politeness and socio-cultural variations of the notion of face. Journal of Pragmatics 18 (4): 309-328.

O'Driscoll, Jim

2007 Brown \& Levinson's face: How it can - and can't - help us to understand interaction across cultures. Intercultural Pragmatics 4(4): 463-492.

Penman, Robyn

1990 Facework and politeness: Multiple goals in courtroom discourse, Journal of Language and Social Psychology, 9, 15-38.

Piirainen-Marsh, Arja

2005 Managing adversarial questions in broadcast interviews. Journal of Politeness Research: Language, Behaviour, Culture 1 (2): 193-217.

Pike, Kenneth

1967 [1954] Etic and emic standpoints for the description of behavior. In: Donald C. Hildum, (ed.), Language and thought: An enduring problem in psychology. Princeton, N.J.: D Van Norstrand Company, 32-39.

Ruhi, Şükriye

2008 Intentionality, communicative intentions and the implication of politeness. Intercultural Pragmatics 5 (3): 287-314.

Scollon, Ron and Suzanne W. Scollon

1981 Narrative, Literacy and Face in Inter-ethnic Communication, New Jersey: Ablex.

Searle, J.R.

1969 Speech Acts: An Essay in the Philosophy of Language, Cambridge: Cambridge University Press.

1975 Indirect speech acts. In: Paul Cole and Jerry L. Morgan (eds) Syntax and Semantics 3. New York: Academic Press, 59-82.

Shimanoff, Susan B.

1977 'Investigating politeness'. In: Elinor Ochs Keenan and Tina L. Bennett (eds.) Discourse across Time and Space, Southern California Occasional Papers in Linguistics, 5, 213-41.

Snow, Catherine E., Rivka Y. Perlmann, Jean Berko Gleason, and Nahid Hooshyar

1990 Developmental Perspectives on Politeness: Sources of Children's Knowledge. Journal of Pragmatics 14: 289-305.

Spencer-Oatey, Helen

1996 Reconsidering power and social distance. Journal of Pragmatics 26: 1-24.

2000 Rapport management: A framework for analysis. In: Helen D. M. Spencer-Oatey (ed.) Culturally Speaking: Managing Rapport Through Talk Across Cultures. London and New York: Continuum, pp. 11-46.

2002 Managing rapport in talk: Using rapport sensitive incidents to explore the motivational concerns underlying the management of relations. Journal of Pragmatics 34 (5): 529-545.

2005 (Im)Politeness, face and perceptions of rapport: Unpackaging their bases and interrelationships. Journal of Politeness Research: Language, Behaviour, Culture 1 (1): 95-119.

2007 Theories of identity and the analysis of face. Journal of Pragmatics 39 (4): 639-656.

2008 Culturally Speaking: Managing Rapport through Talk across Cultures ( $2^{\text {nd }}$ edn) London and New York: Continuum. 
Sperber, Dan and Deirdre Wilson

1995 Relevance: Communication and Cognition. (2 ${ }^{\text {nd }}$ edn) Oxford, U.K. and Cambridge, U.S.A.: Blackwell.

Terkourafi, Marina

2001 Politeness in Cypriot Greek: A frame-based approach. Unpublished PhD dissertation. Cambridge: University of Cambridge.

2002 Politeness and formulaicity: Evidence from Cypriot Greek. Journal of Greek Linguistics 3: 179-201.

2003 Generalised and particularised implicatures of politeness. In: Peter Kühnlein, Hannes Rieser and Henk Zeevat (eds) Perspectives on Dialogue in the New Millennium. Amsterdam: John Benjamins, pp. 151-166.

2005a Beyond the micro-level in politeness research. Journal of Politeness Research: Language, Behaviour, Culture 1 (2): 237-262.

2005b Pragmatic correlates of frequency of use: The case for a notion of "minimal context". In: Sophia Marmaridou, Kiki Nikiforidou and Eleni Antonopoulou (eds) Reviewing Linguistic Thought: Converging Trends for the 21st Century. Berlin: Mouton de Gruyter, pp. 209-233.

Tetreault, Chantal

2009 Reflecting respect: Transcultural communicative practices of Muslim French youth. Pragmatics 19 (1): 65-84.

Thomas, Jenny

1995 Meaning in Interaction: An Introduction to Pragmatics. London and New York: Longman.

Tiisala, Seija

2004 Power and politeness: Languages and salutation formulas in correspondence between Sweden and the German Hanse. Journal of Historical Pragmatics 5(2): 193-206.

Tracy, Karen

1990 The many faces of facework. In: Howard Giles and W. Peter Robinson (eds)

Handbook of Language and Social Psychology, pp.209-226.

Tracy, Karen and Sarah J. Tracy

1998 Rudeness at 911: Reconceptualizing Face and Face Attack. Human Communication Research 25 (2): 225-251.

Turner, Ken

$2003 \mathrm{Wx}=\mathrm{D}(\mathrm{S}, \mathrm{H})+\mathrm{P}(\mathrm{H}, \mathrm{S})+\mathrm{Rx}$ : (Notes towards an investigation). Revue de Sémantique et Pragmatique 13: 47-67.

Watts, Richard J.

1989 Relevance and relational work: linguistic politeness as politic behaviour. Multilingua 8: 131-166.

2003 Politeness. Cambridge: Cambridge University Press.

2005a [1992] Linguistic politeness and politic verbal behaviour: Reconsidering claims for universality. In: Richard J. Watts, Sachiko Ide and Konrad Ehlich (eds) Politeness in Language: Studies in its History, Theory and Practice. Berlin and New York: Mouton de Gruyter, pp. 43-69.

2005b Linguistic politeness research: Quo vadis? In: Richard J. Watts, Sachiko Ide, and Konrad Ehlich (eds) Politeness in Language: Studies in its History, Theory and Practice $\left(2^{\text {nd }}\right.$ edn) Berlin and New York: Mouton de Gruyter, pp. xi-xlvii. 
Watts, Richard J., Sachiko Ide and Konrad Ehlich (eds)

2005a [1992] Introduction. In: Watts, Richard J., Sachiko Ide and Konrad Ehlich (eds.)

Politeness in Language: Studies in its History, Theory and Practice. Berlin and New York: Mouton de Gruyter, pp.1-17.

Watts, Richard J., Sachiko Ide and Konrad Ehlich (eds)

2005b [1992] Politeness in Language: Studies in its History, Theory and Practice. Berlin and New York: Mouton de Gruyter.

Wichmann, Anne

2004 The intonation of please-requests: a corpus-based study. Journal of Pragmatics 36 (9): 1521-1549.

Wierzbicka, Anna

2003 [1991] Cross-Cultural Pragmatics: The Semantics of Human Interaction (2 ${ }^{\text {nd }}$ edn) Berlin and London: Mouton de Gruyter.

Wolfson, Nessa

1988 'The bulge: A theory of speech behaviour and social distance'. In Fine, Jonathan (ed.) Second Language Discourse: A Textbook of Current Research. Norwood, N.J.: Ablex, pp.21-38.

${ }^{1}$ The problem of the limitations of classic communicative theory, particularly with respect to how it copes with interaction, is in fact acknowledged by Brown and Levinson (1987: 48), although critics usually ignore this acknowledgement, as Arundale (2006: 194-5) points out.

${ }^{2}$ Whilst it is clear that this volume did much to set the agenda for the new discursive approach to politeness, it should be noted that not every paper within it could be described as discursive.

${ }^{3}$ In Spencer-Oatey $(2000,2002)$ there were two types of face, "quality face" and "social identity face". In Spencer-Oatey $(2007,2008)$ "relational face" is added. Three categories of similar definition can also be found in Domenici and Littlejohn (2006: 6, 13). - not in ref list ${ }^{4}$ This year also saw the publication of another journal special issue, which, although it is not exclusively devoted to impoliteness, contains a significant number of papers focusing on impoliteness: "(Im)politeness in Spanish-speaking Socio-cultural Contexts" (Pragmatics 18 (4), edited by Diana Bravo).

${ }^{5}$ Leech (2009) argued that taboo language is one of two impoliteness areas which politeness theory, specifically his own, cannot adequately account for. The other concerns the negative acts, threats and curses. 